\title{
The Starunia palaeontological site and idea of the Ukrainian-Polish trans-border geotourist trail "Traces of large extinct mammals, earth wax, oil and salt: from Starunia to Kraków"
}

Stanowisko paleontologiczne w Staruni i idea utworzenia ukraińsko-polskiej trasy geoturystycznej „Śladami olbrzymich wymarłych ssaków, wosku ziemnego, ropy naftowej i soli: od Staruni do Krakowa"

\author{
Maciej J. Kotarba \\ AGH University of Science and Technology, and Society of Research on Environmental Changes "Geosphere", \\ 30-059 Kraków, Al. Mickiewicza 30,30-059Kraków, e-mail: kotarba@agh.edu.pl
}
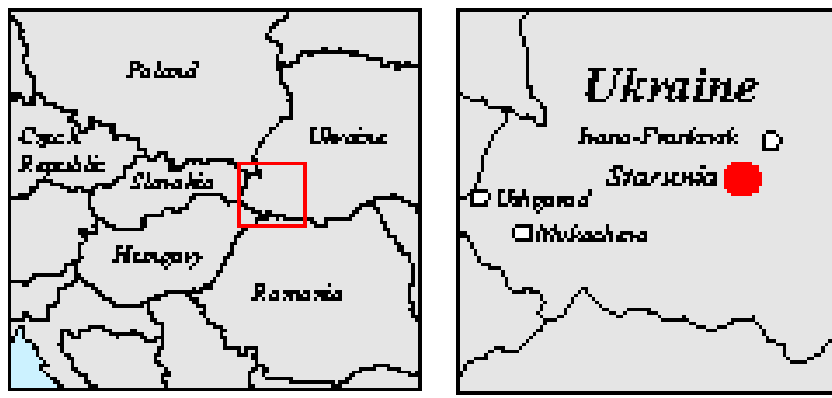

Abstract: The discovery of large Pleistocene mammals at the Starunia ozokerite (named also earth wax) mine (the Ukrainian Carpathians) was a spectacular scientific event on a world scale. The initial discovery was made in 1907 when relics of party preserved mammoth and woolly rhinoceros were excavated. Later, in 1929, the Polish Academy of Arts and Sciences organized a scientific expedition to that site, which resulted in discovery of unique, nearly completely preserved woolly rhinoceros carcass embedded in Pleistocene sediments. A specific combination of brine, oil and clays into which the animal had sunk, is responsible for almost perfect preservation of this animal. The specimens found in 1907 are exhibited at the Natural History Museum in Lviv, Ukraine, whereas the unique specimen excavated in 1929 is displayed at the Natural History Museum in Kraków, Poland. The three sites: Starunia, a small Ukrainian village in which the geopark with the museum and the tourist centre are planned to be developed and two historical towns: Lviv and Kraków, closely connected with the discoveries of extinct large mammals, will be the key sites at the planned, Ukrainian-Polish trans-border geotourist trail "Traces of large extinct mammals, earth wax, oil and salt: from Starunia to Kraków". The trail will also include the sites where occurrences of ozokerite, salt, brine and oil are known, i.e., the substances which preserved the animal carcasses. These are: the historical rock-salt mines in Wieliczka and Bochnia (Poland), Kalush and Stebnik (Ukraine), the Polish resorts - Iwonicz-Zdrój and Rymanów-Zdrój and the most famous Ukrainian resort - Truskavets; one of the oldest oilfields in the world-Bóbrka, where the Ignacy Łukasiewicz Memorial Open-Space Museum of Oil and Gas Industry is located and Boryslav oil and ozokerite field - the largest deposit in the Ukrainian Carpathians. The idea of Ukrainian-Polish trans-border tourist trail is strongly supported by geological, natural and cultural values of the Polish and the Ukrainian Carpathians.

Key words: Starunia palaeontological site, geotourist trail, woolly rhinoceros, salt mine, brine, $\mathrm{Na}-\mathrm{Cl}$ mineral water, ozokerite, Natural History Museums: Lviv (Ukraine) and Kraków (Poland)

Treść: Odkrycia wielkich ssaków plejstoceńskich w kopalni ozokerytu w Staruni (region karpacki, Ukraina) byty spektakularnym wydarzeniem naukowym w skali światowej. W 1907 r. znaleziono szczatki mamuta i nosorożca włochatego. Później, w roku 1929, Polska Akademia Umiejętności zorganizowata ekspedycję, podczas której w osadach plejstoceńskich znaleziono prawie catkowicie zakonserwowany okaz nosorożca wtochatego. Za jego doskonate zachowanie jest odpowiedzialna specyficzna mieszanina solanki, ropy naftowej $i$ iłów, w której utoną olbrzymi ssak. Okazy odkryte w 1907 r. znajduja się w Muzeum Przyrodniczym we Lwowie, a unikatowy egzemplarz znaleziony w 1929 r. w Muzeum Przyrodniczym w Krakowie. Te trzy miejscowości: Starunia, niewielka wioska ukrainska, w której planuje się utworzenie geoparku i centrum muzealniczo-turystycznego oraz dwa historyczne miasta Lwów i Kraków, ściśle zwiqzane z tymi znaleziskami, będa stanowić główne, węzłowe miejsca planowanej ukraińsko-polskiej trasy geoturystycznej „Śladami olbrzymich wymartych ssaków, wosku ziemnego, ropy naftowej i soli od Staruni do Krakowa". Do trasy zostana też właczone miejsca zwiqzane z wystepowaniem ozokerytu, soli, solanki i ropy naftowej, a więc czynnikami, które spowodowaty zakonserwowanie tych zwierzat: historyczne kopalnie - Wieliczka i Bochnia oraz Katusz i Stebnik, polskie uzdrowiska - Iwonicz-Zdrój i Rymanów-Zdrój oraz znane uzdrowisko ukrainskie - Truskawiec; złoże ropy naftowej w Bóbrce - jedno z najdawniej eksploatowanych złóż na świecie, w której znajduje się Skansen - Muzeum Przemystu Naftowego i Gazowniczego im. Ignacego Łukasiewicza oraz złoże ropy naftowej i ozokerytu Borystaw - największe w Karpatach ukrainskich. Za realizacja projektu utworzenia ukraińsko-polskiej trasy geoturystycznej przemawiaja walory geologiczne, przyrodnicze i kulturowe Karpat polskich i ukrainskich.

Słowa kluczowe: stanowisko paleontologiczne Starunia, trasa geoturystyczna, nosorożec włochaty, kopalnia soli, solanka, woda mineralna $\mathrm{Na}-\mathrm{Cl}$, ozokeryt, ropa naftowa, muzea przyrodnicze: Lwów i Kraków 


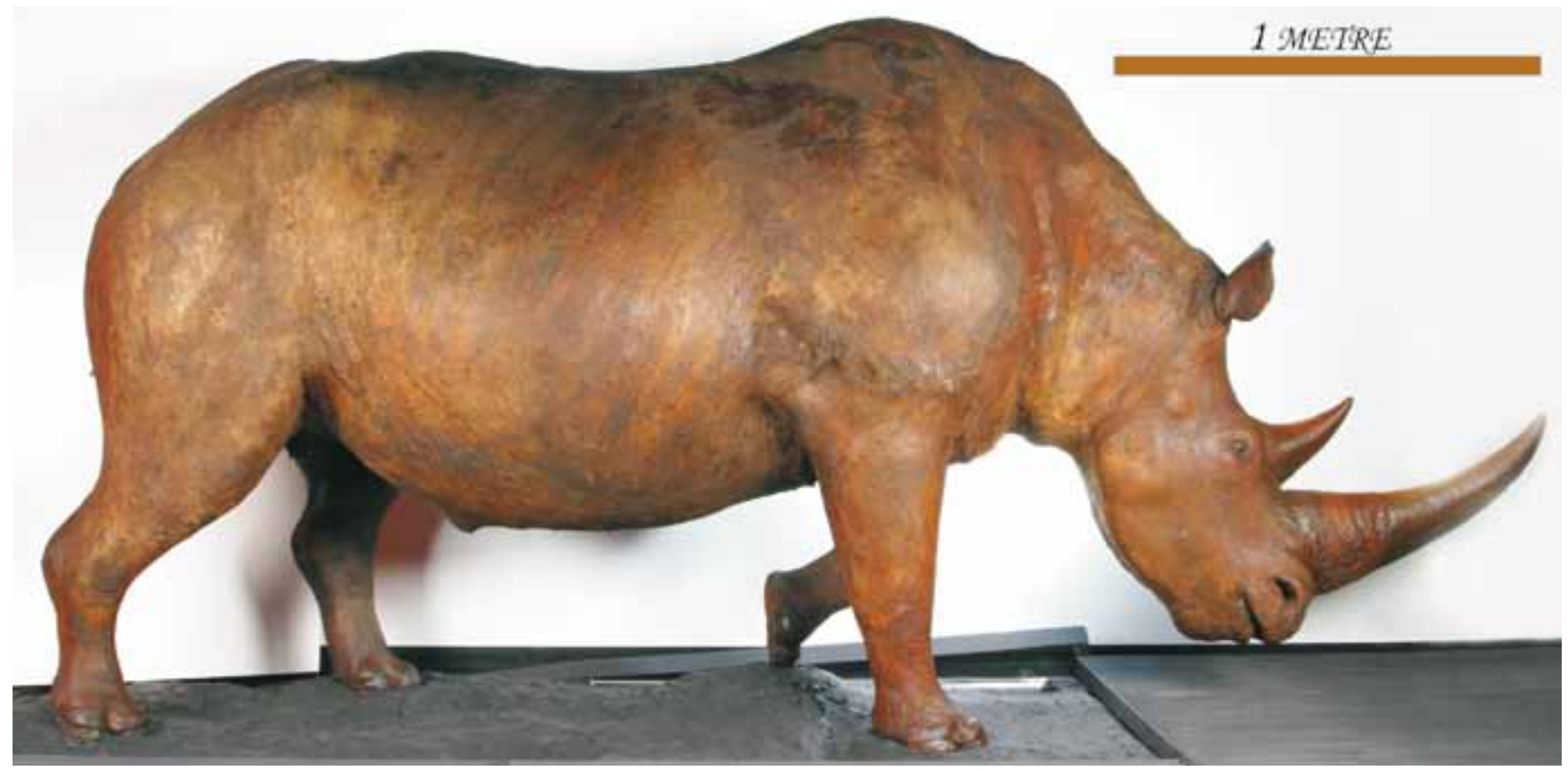

Fig. 1. The "second” woolly rhinoceros after conservation at the Natural History Museum in Kraków. Phot. P. Witosławski • „Drugi” nosorożec włochaty po pracach konserwatorskich w Muzeum Przyrodniczym w Krakowie. Fot. P. Witosławski

\section{Introduction}

The discovery of large Pleistocene mammals dated at 40,000 - 35,000 years BC (Kuc et al., 2005; Kuc et al., 2011) at the Starunia ozokerite (earth wax) mine (about 130 kilometres southeast of Lviv, Ukraine) was a spectacular scientific event on a world scale (e.g., Alexandrowicz, 2004, 2005). The initial discovery was made in 1907 when relics of a partly preserved mammoth and rhinoceros were excavated within the Pleistocene clays on the depths 12.5 and 17.6 metres, respectively (Bayger et al., 1914). Later, in 1929, the Polish Academy of Arts and Sciences organized a scientific expedition to the site and discovered a nearly complete preserved woolly rhinoceros carcass at a depth of 12.5 metres (Fig. 1). A unique combination of brine, oil and clays into which the animal had sunk, is responsible for almost perfect preservation of this specimen. Since this discovery the remnants of two more rhinoceroses have been found at this site. Moreover, numerous specimens of other fossil fauna and flora were discovered. These specimens are now displayed at museums in Poland and Ukraine: those found in 1907 are exhibited at the Natural History Museum of the National Academy of Sciences of Ukraine (the former Dzieduszycki's Family Museum) in Lviv, Ukraine and specimens excavated in 1929 are displayed at the Natural History Museum and in the Institute of Systematics and Evolution of Animals of the Polish Academy of Sciences, both in Kraków, Poland (Fig. 1). Moreover, in Lviv, at the Mickiewicz Square, close to the exit of the Kopernik Street (both historical names have survived) there is the pharmacy "Under the Golden Star", established in 1828 by Peter Piotr Mikolasch. Here, in 1853, the pharmacist Ignacy Lukasiewicz and his collaborator Jan Zeh distilled for the first time the kerosene (lamp oil) from the Carpathian oil (Przyrowski, 1961).

Moreover, the Starunia area has the following spectacular features: abandoned ozokerite mine (Fig. 2); mud volcanoes and oil and gas surface seeps and archaeological sites. Starunia village is located in the picturesque area of the ForeCarpathian region. From this site snowy, 2,000-meter-high peaks of the Gorgany Mts can be seen (Fig. 3).

The three sites: Starunia - small village in the Ukrainian Carpathians and two historical cities - Kraków and Lviv (Fig. 4), closely connected with the unique palaeontological finding will be the key points at the planned UkrainianPolish trans-border geotourist trail "Traces of large extinct mammals, earth wax, oil and salt: from Starunia to Kraków" (Adamenko et al., 2009; Chornobay \& Drygant, 2009; and Kubiak, 2009). In Starunia the geopark, the museum and the tourist centre are planned, belonging to the UNESCO network (Adamenko et al., 2009). Moreover, the trail will include other sites related to the occurrence of the earth wax (ozokerite), salt, brine and oil, hence, the factors which contributed to the preservation of the bodies of large extinct mammals. In the Carpathian region there are historical rock-salt mining sites: Wieliczka and Bochnia mines in the Polish part (Wiewiórka et al., 2009), and Kalush and Stebnik mines (Fig. 4) in the Ukrainian part (Bukowski \& Czapowski, 2009). There are also springs of brines and saline mineral waters utilized in many health resorts. The separate papers present the most famous Ukrainian resort - Truskavets (formerly Truskawiec) (Radwański, 2009a) as well as the Polish resorts - Iwonicz-Zdrój and Rymanów-Zdrój (Radwański, 2009b).

The Carpathians constitute one of the oldest petroleumproducing regions in the world. The exploitation of oil has started in 1854 and that of natural gas in 1920 (AOGFU, 1998; Kotarba \& Koltun, 2006). The separate papers deal with one of the oldest oilfields exploited in Poland - the famous Bóbrka (Fig. 4), where the Ignacy Łukasiewicz Memorial Open-Space Museum of Oil and Gas Industry exists (Radwański, 2009b) and in Ukraine - Boryslav (Fig. 4) (Radwański, 2009a). 


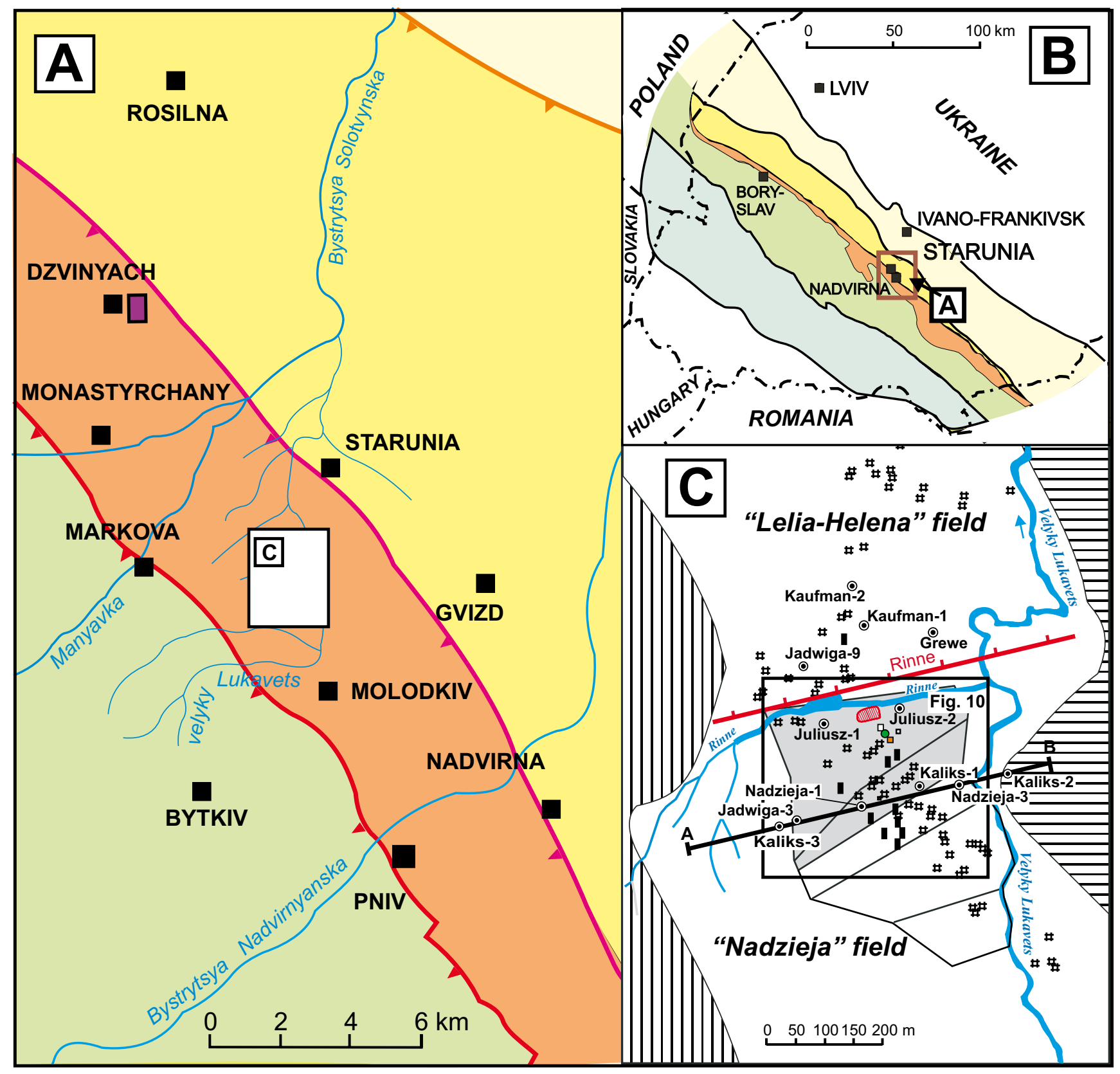

Unit:

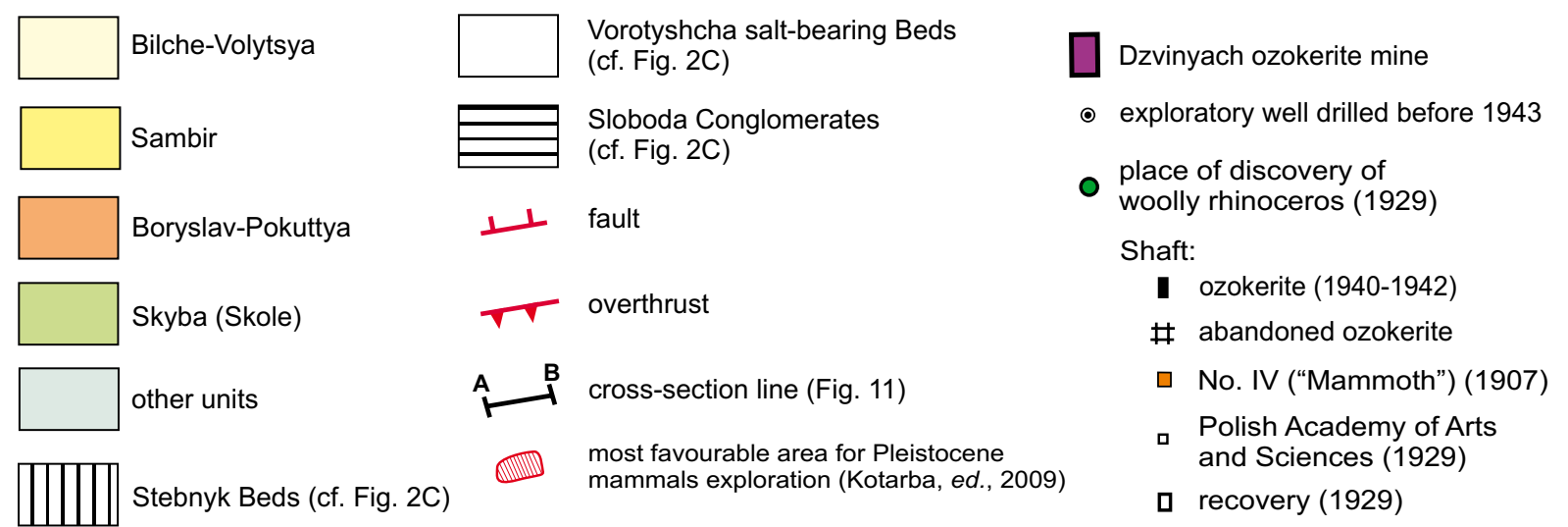

abandoned "Michajłowa" and "Dmytruk" ozokerite mines (1886-1888)

Fig. 2. (A \& B) Sketch-maps of major tectonic units of the Ukrainian Outer Carpathians and the Carpathian Foredeep in the DzvinyachNadvirna area, and (C) geological map of the Starunia ozokerite deposit with the most favourable exploration area for Pleistocene fossil mammals, determined from the results of interdisciplinary studies in the years 2006-2009 (Kotarba, ed., 2009) • (A, B) Mapy poglądowe przedstawiające główne jednostki tektoniczne ukraińskich Karpat zewnętrznych i zapadliska przedkarpackiego w rejonie DźwiniaczNadwórna oraz (C) mapa geologiczna złoża ozokerytu Starunia z lokalizacją najkorzystniejszej strefy poszukiwań wymarłych ssaków, wyznaczonej na podstawie wyników interdyscyplinarnych badań w latach 2006-2009 (Kotarba, ed., 2009) 
The idea of the Ukrainian-Polish trans-border geotourist trail "Traces of large extinct mammals, earth wax, oil and salt: from Starunia to Kraków" is supported by geological, natural and cultural values of the Polish and the Ukrainian Carpathians together with inevitable protection of these natural resources in the times of dynamic economic growth of the region.

It must be emphasized that the Carpathian region has experienced long and complicated historical events. Before 1349 the area east of Przemyśl had been under the control of the Dutchy of Halich. In the years 1349-1772 it was the part of the Polish Kingdom and between 1772 and 1918 it belonged to the Austrian Empire (1772-1869) and later to the Austro-Hungarian Monarchy (1869-1918).

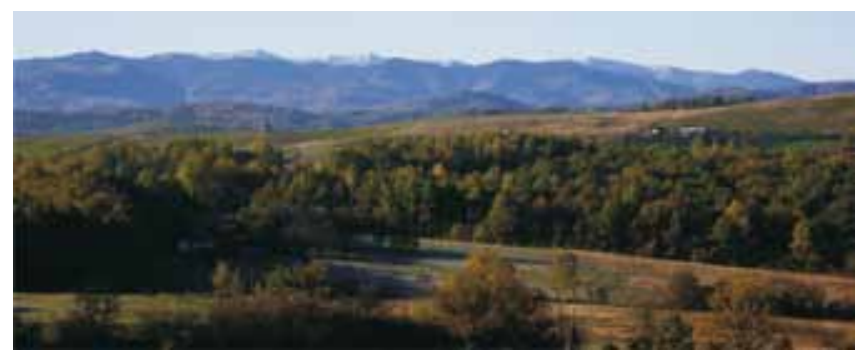

Fig. 3. Panorama of the Gorgany Mts. View from Starunia. Phot. T. Sokołowski • Panorama Gorganów. Widok ze Staruni. Fot. T. Sokołowski
Between 1919 to 1939 it was again a part of Poland. After German occupation (1939-1945) the region was divided: the western part remained in Poland and that eastern part was incorporated to the Soviet Union; since 1993 it is a part of independent Republic of Ukraine.

\section{Outline of geology}

The Polish and Ukrainian Carpathians represent the central segment of the Carpathian arc which extends between Vienna Forest and Iron Gate on the Dunabe in Romania (Fig. 4). The Outer (Flysch) Polish and Ukrainian Carpathians are the outer part of a young Alpine orogenic belt of nappe-thrust structure composed of numerous complexes of generally calcareous sandstones, and shales (mudstones and claystones) in the Skole (Skyba), Silesian (Krosno), Sub-Silesian, Dukla, Grybów, Magura, Porkulets, Rakiv, Marmarosh and Chornohora units, ranging in age from Late Cretaceous to Oligocene/Early Miocene (Cieszkowski et al., 1985; Ślączka \& Kaminski, 1998; Ślączka et al., 2006). The equivalent units to the Skyba and Krosno units in Ukraine are termed the Skole and Silesian units in Poland.

The Carpathian Foredeep is divided into the two basins: outer and inner (Oszczypko, 1997). The folded Zgłobice, Stebnik (called Sambir in Ukraine) and Boryslav-Pokuttya

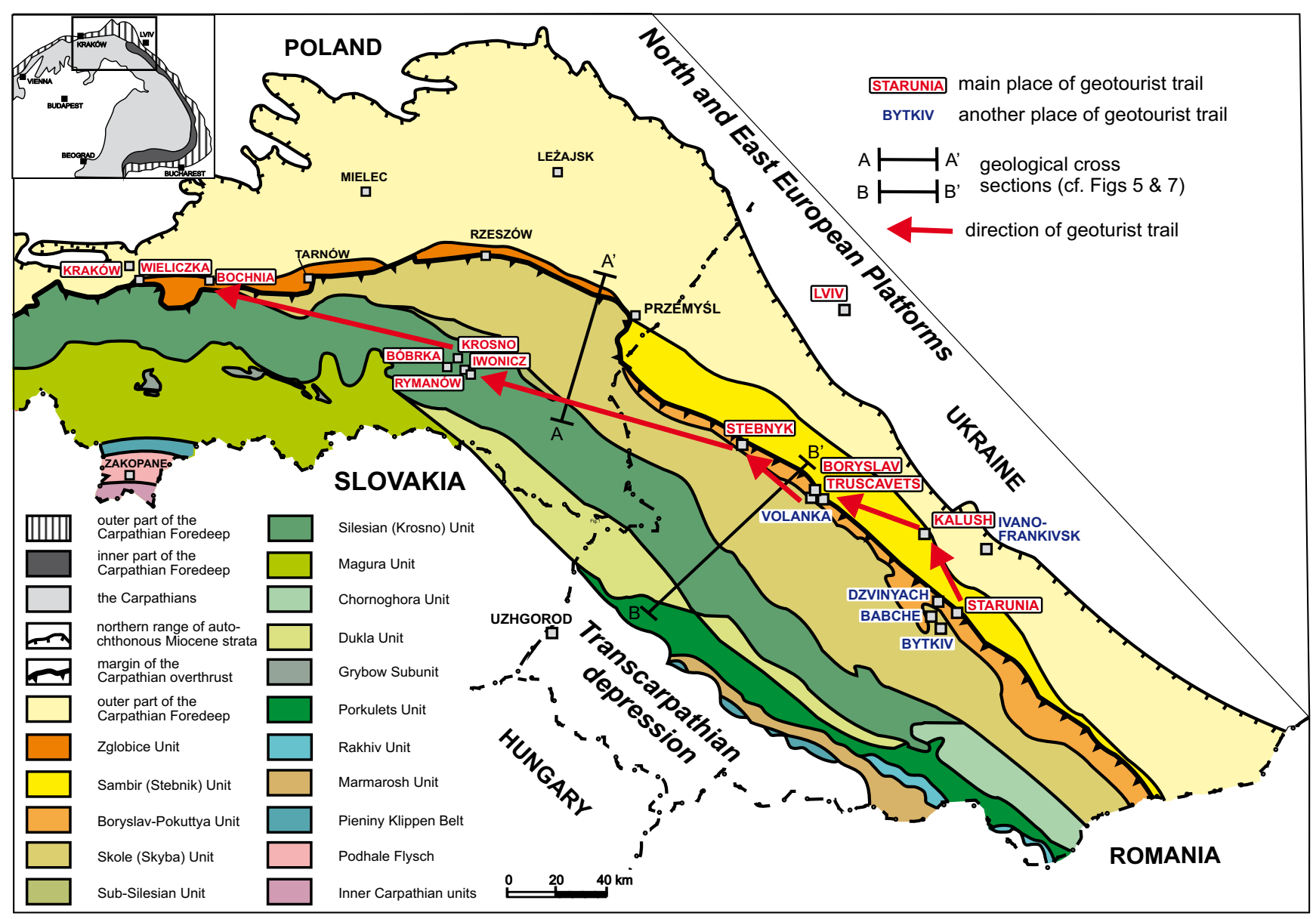

Fig. 4. Sketch-map of major tectonic units of the Polish and Ukrainian Carpathians, and their foreland with the location of sites at the Ukrainian-Polish trans-border geotourist trail “Traces of large extinct mammals, earth wax, oil and salt: from Starunia to Kraków” • Szkic przedstawiający główne jednostki tektoniczne polskich i ukraińskich Karpat oraz ich przedgórza z lokalizacją miejscowości na ukraińsko -polskiej trasie geoturystycznej „Śladami olbrzymich wymarłych ssaków, wosku ziemnego, ropy naftowej i soli: od Staruni do Krakowa” 


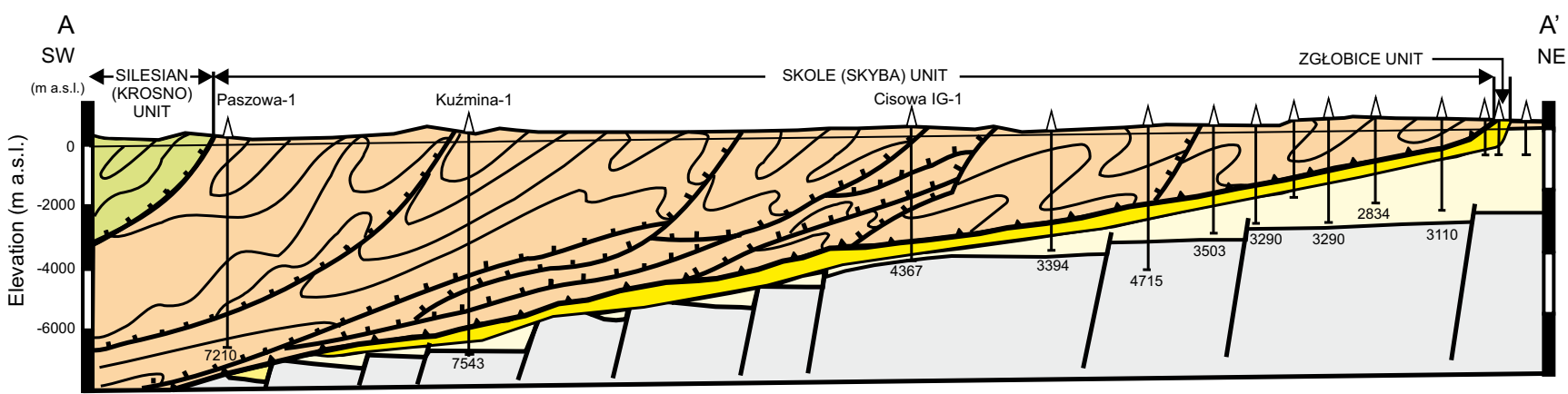

$$
\begin{aligned}
& \text { Precambrian and Palaeozoic- } \\
& \text { Mesozoic basement } \\
& \text { Silesian (Krosno) Unit } \\
& \text { Skole (Skyba) Unit }
\end{aligned}
$$
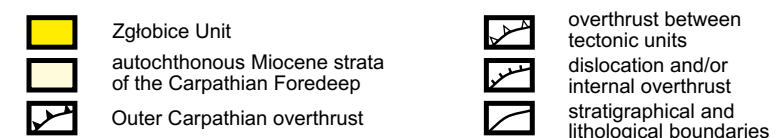

Fig. 5. Schematic geological cross-section A-A' through the eastern part of the Polish Outer Carpathians and the Carpathian Foredeep, modified after Cieszkowski et al. (1985). For location of section line see Fig. $4 \bullet$ Schematyczny przekrój geologiczny A-A’ przez wschodnią część polskich Karpat zewnętrznych i zapadliska przedkarpackiego, według Cieszkowskiego et al. (1985), zmienione. Lokalizacja - patrz Fig. 4

units from sedimentological point of view belong to the inner part of the Carpathian Foredeep but for tectonic reasons belong to the Carpathian overthrust. Zgłobice Unit occur only in Poland and Boryslav-Pokuttya Unit only in Ukraine. The outer basin (= Bilche-Volytsya unit in Ukrainian part) is filled with autochthonous Miocene sediments (Krobicki et al., 2008; Oszczypko, 1997; Oszczypko et al., 2006). Generalized geological cross-sections and lithostratigraphic columns with distribution of petroleum reservoirs in selected structural units of the Polish and Ukrainian Carpathians are presented in Figs $5 \& 6$ and Figs $7 \&$ 8, respectively.

In Starunia area, the Quaternary sediments rest upon on the sedimentary strata of the Boryslav-Pokuttya Unit. The first geological map of the Starunia area (Fig. 9) was prepared by Zuber in 1888, and updated by J. Łomnicki (see Bayger et al., 1914).

\section{The ozokerite (earth wax)}

In the middle of the 19th century the Austrian mineralogist F. Glocker proposed the name "ozokerite" (derived from the Greek "smelling wax") for the natural earth wax. Recently, the term "ozokerite" has become more popular. At the same time Robert Doms discovered thick lodes of earth wax near Boryslav (Alexandrowicz, 2004). The world largest ozokerite deposits occur in the Ukrainian part of the Carpathian Foredeep. Small deposits are known from Uzbekistan and Turkmenistan, and minor occurrences were described from the USA, China, Myanmar (formerly Birma), Spain, Italy, Egypt and Romania (Bojko \& Sozański, 2004).

In the Carpathian region ozokerite veins hosted at shallow depth in the Lower Miocene salt-bearing Vorotyshcha Beds were discovered in 1855 by Robert Dombs, an entrepreneur from Lviv (Bojko \& Sozański, 2004). Ozokerite exploitation has started first in Boryslav and in nearby Volanka (1857), then in Starunia (1868) and Dzvinyach (1870), and, some years later, in Pomyarky near Truskavets but the largest mining centre was Boryslav where two mining companies were active together with several dozens owners of a few shafts and several hundred owners of single mining lots. In 1875, totally 4,000 shafts were in operation. During the following years, foreign (especially
French) companies began to control a part of ozokerite exploitation. In the eastern part of the mining area the large "Franz Joseph" mine was built. This relatively well-organized and well-managed enterprise was completely destroyed by an unfortunate gas explosion on March 1st, 1887. However, even this tragic accident was insufficient to improve the mining techniques used in the district (Alexandrowicz, 2004, 2005; Bojko \& Sozański, 2004).

The early mining technology was simple and included digging of shallow wells and shafts. Over the next few years the mining depths increased to 100 and even to 200 metres below the surface. The wells and shafts were dug close to each other, sometimes only several metres apart, but their location was rather chaotic. Workings were cased with boards, planks, woven wickers, timber beams and clay. As soon as wax deposit was reached, horizontal gangways were cut from the shaft bottom. Neither skillful supervising staff nor experienced miners with at least a basic knowledge of mining technologies were available. Consequently, a high rate of fatal or life-threatening mine accidents was typical of that period of ozokerite exploitation (Alexandrowicz, 2004, 2005; Bojko \& Sozański, 2004). The ozokerite "ore" hoisted to the surface was boiled at 60 to $80^{\circ} \mathrm{C}$ in large, wood-burning water boilers. The wax present in the ore melted and floated at the surface whereas impurities, i.e. sand and clays, were deposited at the bottom of a boiler (Bojko \& Sozański, 2004). The resulting product was natural paraffin suitable for manufacturing candles commonly used in those days. This product effectively replaced much more expensive beeswax. Later, the range of ozokerite applications expanded: it was used in medicine, as an insulator and as a component of greases and lubricants. It is worth mentioning that in the $1880 \mathrm{~s}$, the earth wax mined and purified in Boryslav was successfully used to insulate the first undersea telegraph cable laid on the Atlantic Ocean floor between Europe and North America (Alexandrowicz, 2004; Bojko \& Sozański, 2004). Improper mining technology caused catastrophic flooding of Boryslav mine in 1955 (Bojko \& Sozański, 2004). Estimated total production of ozokerite from Boryslav deposit until the beginning of 2000 exceeded 410,000 metric tones (Bojko \& Sozański, 2004). 


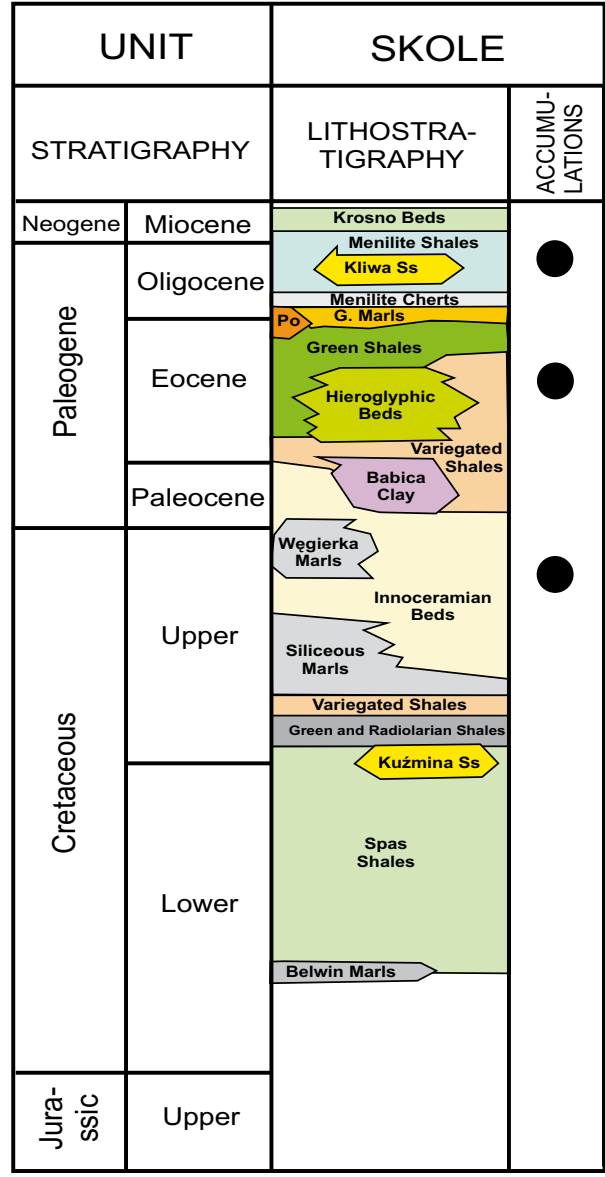

oil and gas condensate field
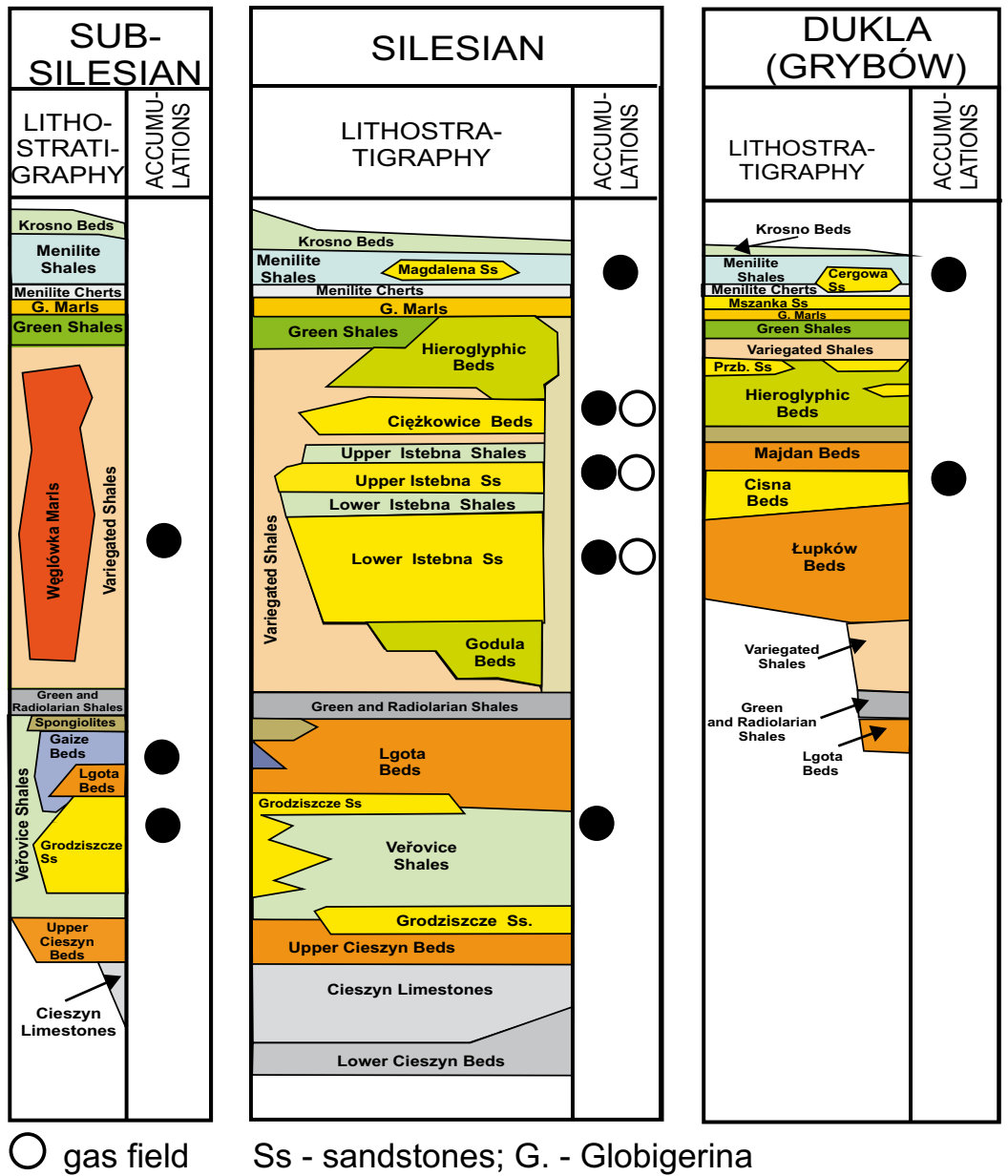

Ss - sandstones; G. - Globigerina

Fig. 6. Generalized lithostratigraphic column for the selected tectonic units of the Polish Outer Carpathians with distribution oil and gas accumulations, modified after Ślączka \& Kamiński (1998) • Uogólniony profil litostratygraficzny dla poszczególnych jednostek tektonicznych polskich Karpat zewnętrznych oraz rozkład akumulacji ropy naftowej i gazu ziemnego, według Ślączki i Kamińskiego (1998), zmienione.

The ozokerite mining in Starunia commenced in 1868 (Alexandrowicz, 2004; Adamenko et al., 2005a). In 1886, there were 109 operating shafts in "Michajłowa" and "Dmytruk" mines, belonging to a dozen of owners. In 1907, the "Michajłowa-Dmytruk" Mine owned by the "J. Campe and Co." mining enterprise based in Hamburg started operations. The mining lot included cadastral parcels Nos 3324 to 3330 (Kotarba \& Stachowicz-Rybka, 2008). In the years 1907-1908, several new shafts were sunk and the existing shafts were reconstructed. The general map (Fig. 10) shows the locations of shafts and wells completed in the years 1886-1942 (Kotarba \& Stachowicz-Rybka, 2008). In the Starunia deposit ozokerite was discovered at depths ranging from 10 to about 500 metres below the surface.

The ozokerite is hosted in the Lower Miocene salt-bearing Vorotyshcha Beds, which rest upon the flysch strata of the Boryslav-Pokuttya Unit. The Boryslav-Pokuttya Unit forms several, stacked slice-folds, each of them built of a flysch succession covered by molasse sediments. In the top part of the flysch succession, the Oligocene-Lower Miocene Menilite Beds occur (Fig. 11). This unit comprises intercalated black claystones and mudstones, which are excellent hydrocarbon source rocks, and the Kliwa Sandstones, which are hydrocarbon reservoirs. Another important reservoir horizon in the Starunia area is located in the Middle Eocene sandsto- nes (Koltun et al., 2005). The flysch succession of the Boryslav-Pokuttya Unit is covered by the Lower Miocene Polyanitsya Beds (Fig. 8), which are absent from the Starunia fold, as well as the Vorotyshcha Beds, which host rock-salt and potassium salt seams as well as ozokerite veins and nests (Fig. 11). The youngest unit of the Lower Miocene complex is named the Stebnyk Beds (Fig. 8).

The salt-bearing Vorotyshcha Beds, up to 500 metres thick, comprise claystones and mudstones intercalated by sandstones and thin-bedded marls with layers, lenses and veinlets of gypsum, pyrite, native sulphur, rock-salt and potassium salt (Alexandrowicz, 2004; Korin, 2005). Ozokerite veins and layers, usually from 2 to 30 centimetres (rarely up to several metres) thick, occur exclusively within the Lower Miocene salt-bearing Vorotyshcha Beds (Fig. 11). In the Starunia area the top surface of the Vorotyshcha Beds occurs beneath the Quaternary sediments, at a maximum depth of 17 metres (Sokołowski et al., 2009). The Starunia ozokerite deposit is cut by the Rinne Fault (Fig. 2C), which extends from the Rinne Stream to the south (i.e., to the "Nadzieja" mining field) and to the north (to the "Lelia-Helena" mining field; Fig. 2C). The "Nadzieja" field is an eroded anticline which axial surface is inclined to the southwest. The "Lelia -Helena" field is a full anticline (Kotarba, ed., 2009).

The ozokerite reserves of the "Nadzieja" field were estimated at about 400,000 metric tons. Those of the "Lelia" field 


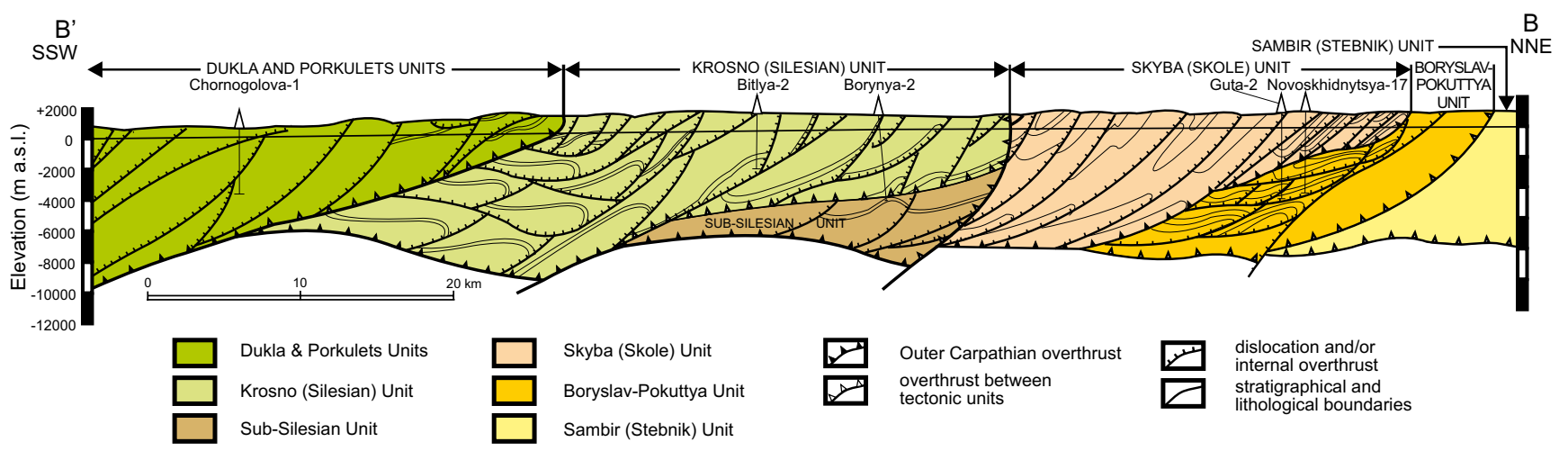

Fig. 7. Schematic geological cross-section B-B' through the western part of the Ukrainian Outer Carpathians and the Carpathian Foredeep, modified after AOGFU (1998). For location of section line see Fig. 4 • Schematyczny przekrój geologiczny B-B' przez zachodnią część Karpat zewnętrznych i zapadliska przedkarpackiego, według AOGFU (1998), zmieniony. Lokalizacja - patrz Fig. 4

can be even larger. Total production from the Starunia deposit between 1868 and 1960 is estimated at over 5,000 metric tons (Alexandrowicz, 2004; Kotarba \& Stachowicz-Rybka, 2008), which means that the remaining mineable ozokerite reserves are still significant. In the years 1885-1942, in the Starunia area 20 petroleum exploratory boreholes were drilled (Kotarba, 2009). Industrial accumulations of oil and gas were encountered only in the Nadzieja-1 well. In 1929, daily oil production from the well was $4,000 \mathrm{~kg}$ but decreased to only $300 \mathrm{~kg}$ in 1940 (Kotarba, 2009). This well was closed just after the World War II due to technical failure. Today, the natural gas burns over destroyed wellhead of the Nadzieja-1 borehole (Fig. 12).

It was found that in the Starunia fold the Vorotyshcha Beds were sliced, fractured and cracked during the Carpathian overthrust movements. During migration of oil and gas from the flysch strata towards the surface most of gaseous hydrocarbons were released to the atmosphere, the liquid hydrocarbons saturated the Quaternary sediments, and the higher hydrocarbons formed ozokerite veins (Fig. 11).

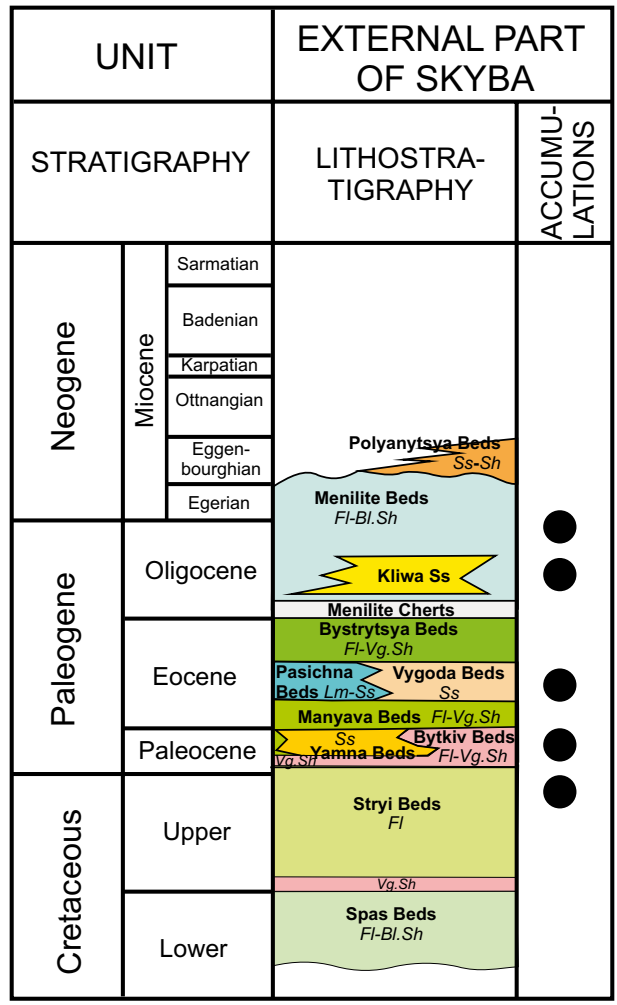

oil and gas condensate field

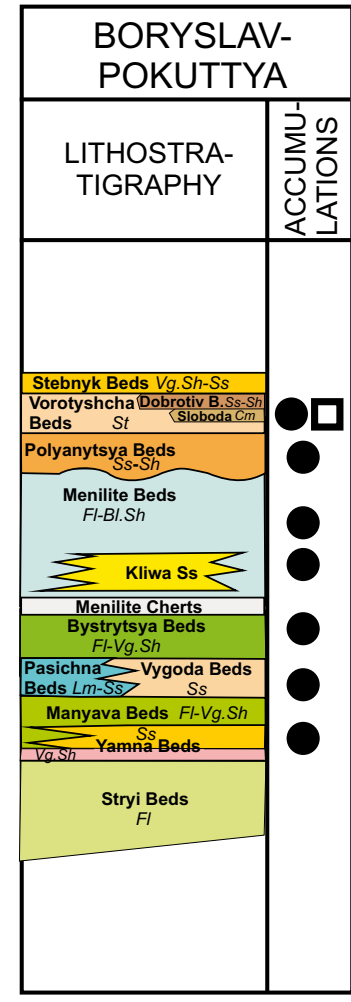

ozokerite field
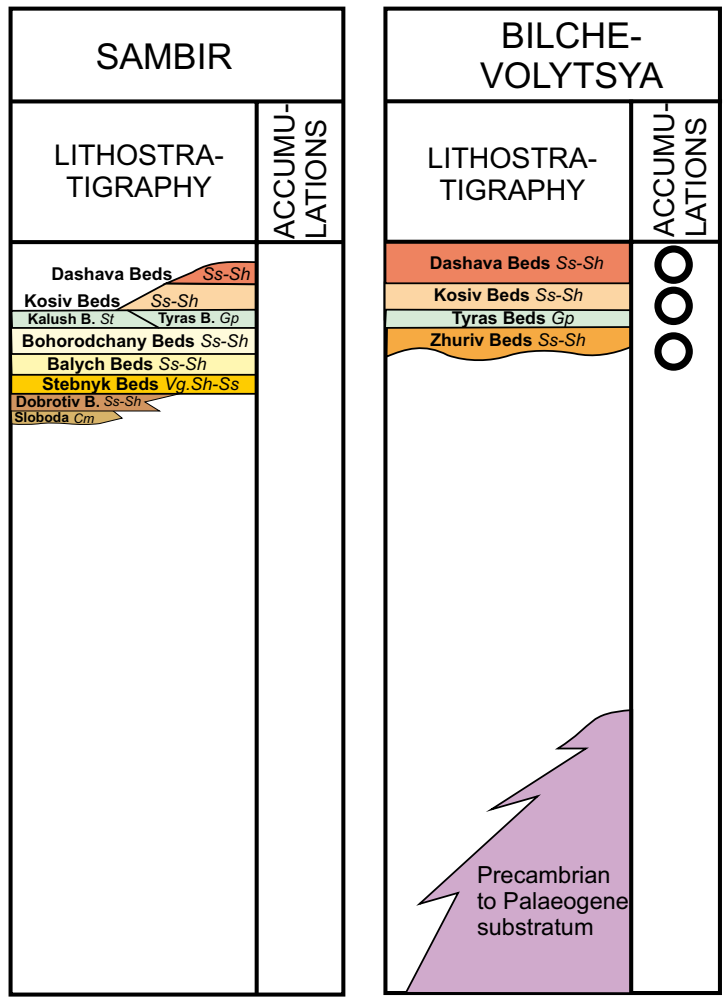

FI - flysch; FI-BI.Sh - flysch with black shales; FI-Vg.Sh - flysch with variegated shales; Ss - sandstones; Ss-Sh - sandstones and shales intercalations; Lm - limestones; Cm - conglomerates; St - salt-bearing deposits; Gp - gypsum and anhydrite, B. - Beds

Fig. 8. Generalized lithostratigraphic columns of the Skyba, Boryslav-Pokuttya, Sambir and Bilche-Volytsya units (autochthonous Miocene of the Carpathian Foredeep), showing the distribution of flysch and molasse facies in the Starunia area, and ozokerite, oil and gas accumulations, after Koltun et al. (2005) and Kotarba \& Koltun (2006) • Uogólnione profile litostratygraficzne jednostek: skibowej (skolskiej), borysławsko-pokuckiej, samborskiej (stebnickiej) i bilcze-wolickiej (miocen autochtoniczny zapadliska przedkarpackiego) przedstawiający rozkład facji fliszowych i molasowych w strefie Staruni oraz akumulacje ozokerytu, ropy naftowej i gazu ziemnego, według Koltuna et al. (2005) oraz Kotarby i Koltuna (2006) 


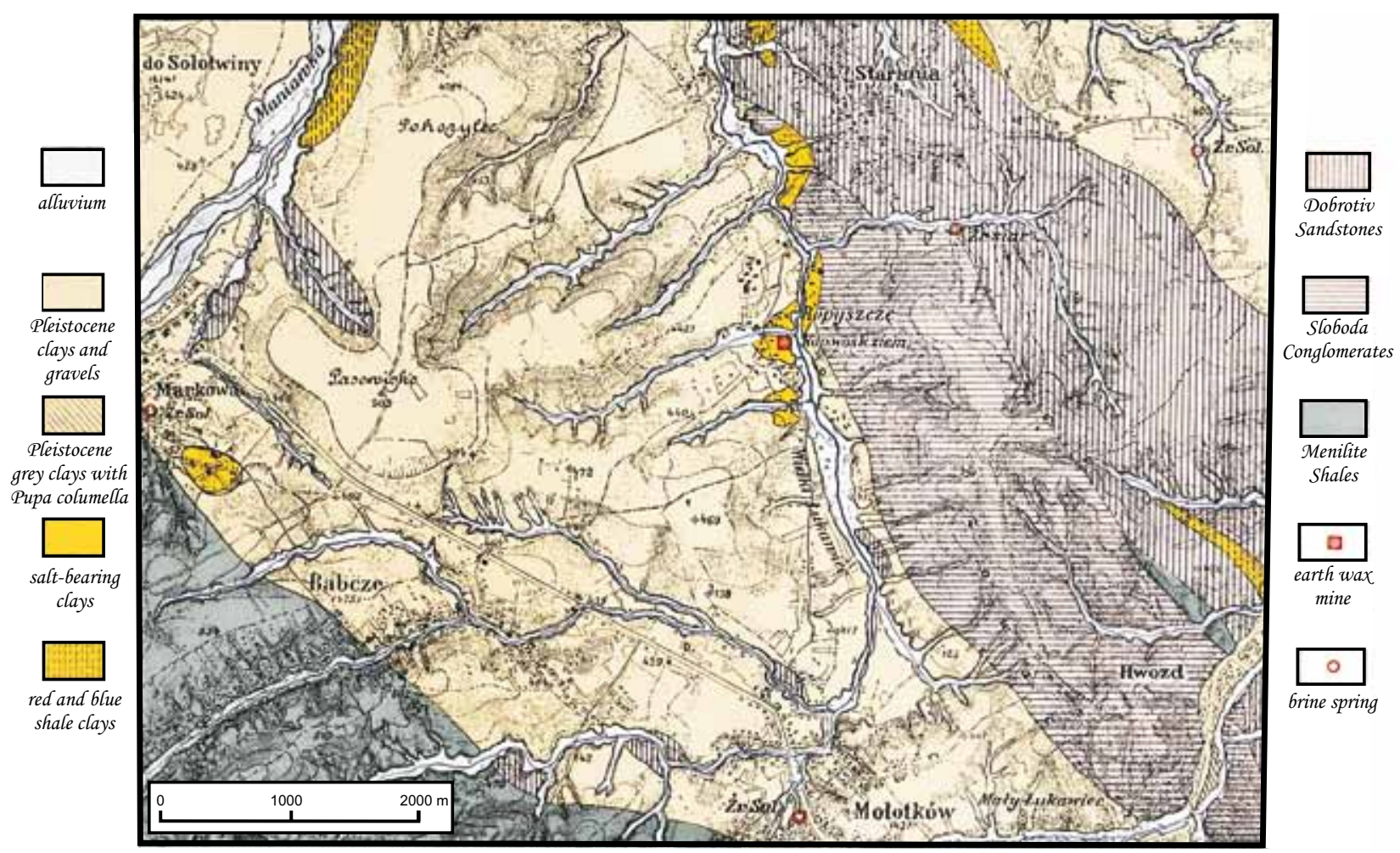

Fig. 9. Original geological map of the Starunia area by J. Łomnicki with data of R. Zuber (Bayger et al., 1914) $\bullet$ Oryginalna mapa geologiczna rejonu Staruni opracowana przez J. Łomnickiego zawierająca dane R. Zubera (Bayger et al., 1914)

As a result, in the rocks of the Starunia fold one of the largest world accumulations of ozokerite originated but the fold is not a perspective structure for further petroleum exploration.

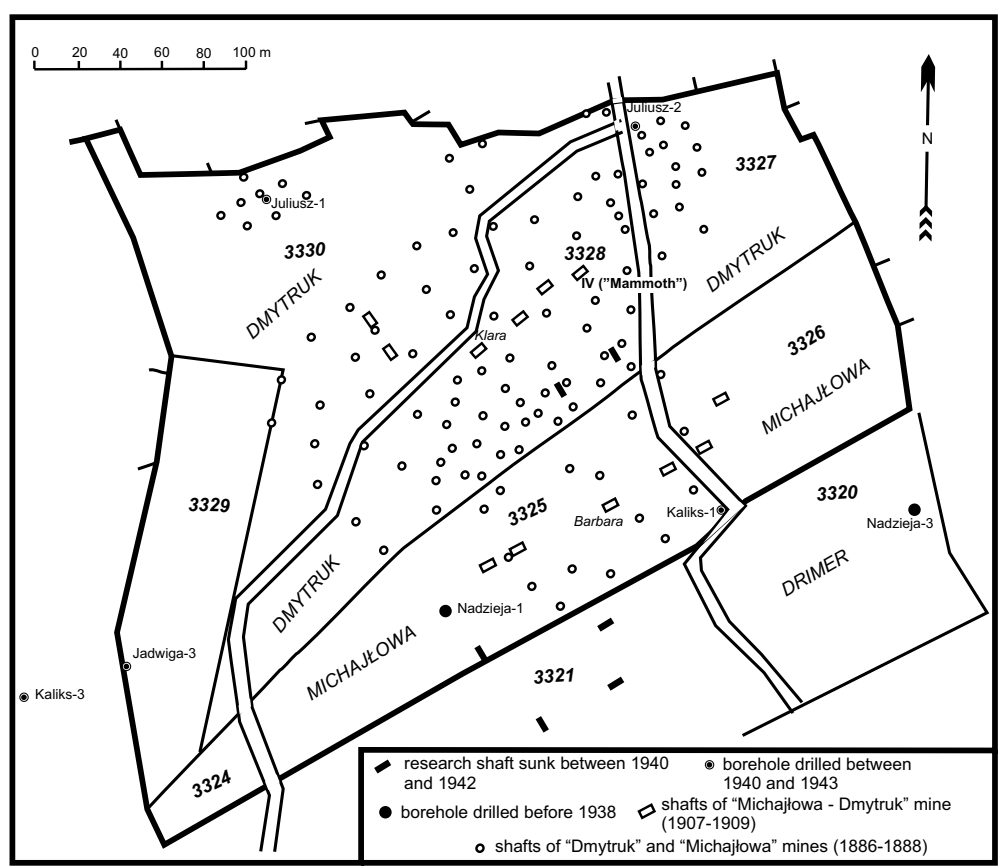

Fig. 10. Location map of shafts and exploratory wells at the abandoned "Michajłowa-Dmytruk" mine in Starunia. Mining lots cover cadastral parcels Nos. 3324, 3325, 3326, 3327, 3328, 3329 and 3330. After Kotarba \& Stachowicz-Rybka (2008). Dmytruk, Michajłowa and Drimer - names of mining lots • Mapa lokalizacyjna szybów i odwiertów poszukiwawczych kopalni "MichajłowaDmytruk” w Staruni na parcelach katastralnych 3324, 3325, 3326, 3327, 3328, 3329 i 3330 . Według Kotarby i Stachowicz-Rybki (2008). Dmytruk, Michajłowa i Drimer - nazwy działek kopalnianych
Nevertheless, oil, which still seeps at the surface forming "mud volcanoes", "oil eyes" and even small ponds (Kotarba, d., 2005; Kotarba et al., 2008), is one of the most important genetic factors of ozokerite deposits. Liquid hydrocarbons, which occur in the surface seeps and which saturate the relics of woolly rhinoceroses are genetically related to oil reservoired in the Oligocene/Eocene strata of the Boryslav-Pokuttya Unit, i.e. the rock succession which builds the Starunia fold and the adjacent structures: Bytkiv, Gvizd, Markova and Monastyrchany. These hydrocarbons were generated from the Oligocene Menilite Beds (Kotarba, 2002; Kotarba, ed., 2009).

\section{Oil and gas occurrence}

The frontal part of the Flysch Belt of the Polish and Ukrainian Carpathians constitute one of the oldest petroleum-producing regions in the world. The exploitation of oil started in 1854 and that of natural gas in 1920 (AOGFU, 1998).

The main petroleum fields are concentrated within the frontal part of the Outer (Flysch) Carpathian overthrust (the Cretaceous-Palaeogene flysch sequence), the Boryslav-Pokuttya Unit of the inner part of the Carpathian Foredeep, and the Miocene gas-bearing Molasse sequence of the outer part of the Carpathian Foredeep named Bilche-Volytsya Unit in Ukraine (Fig. 4). Oil and gas fields occur also within the Palaeozoic-Mesozoic basement of the Outer Carpathians and the Carpathian Foredeep. 
More than 70 gas fields discovered in the autochthonous Miocene strata in the Polish Carpathian Foredeep and about 40 gas fields in the Ukrainian Carpathian Foredeep contain practically only microbial methane accompanied by small amounts of higher gaseous hydrocarbons (Kotarba, 1998; Kotarba \& Koltun, 2011).

Sixty-seven oil and 16 gas deposits were discovered in the flysch strata of the Polish part of the Carpathians, most of them in sandstone reservoirs within the Silesian and Skole units (46 and 14, respectively) (Karnkowski, 1999). Several oil and gas fields were found in Skyba (Skole) and Krosno (Silesian) units in the Ukrainian Outer Carpathians. The sandstone reservoirs occur in the different lithostratigraphic beds from the Lower Cretaceous to Oligocene (Figs 6 \& 8). The Boryslav-Pokuttya nappe is the main oil-bearing unit in the Ukrainian Carpathian Foredeep. Major oil fields occur in deeply buried anticlines along the front of the Skyba nappe. Boryslav oil and ozokerite field is the largest oil deposit in the Ukrainian Carpathians (Fig. 13).

The Boryslav-Pokuttya Unit form the Starunia fold which hosts insignificant quantities of oil and gas, but to the south and southwest from the fold both the Paleogene and the Neogene reservoirs of the Boryslav-Pokuttya and Skyba units host six oil and gas fields: Gvizd, Southern (Pivdenny) Gvizd, Monastyrchany, Pniv, Pasichna and Bytkiv-Babche (Koltun et al., 2005). A geological cross-section through the BitkivBabche oil and gas condensate field - the second in size in the Ukrainian Carpathians, is presented in Fig. 14.

\section{Salt mines and brines}

As mentioned above, salts and brines together with oil were the principal components, which contributed to the preservation of soft tissues of large extinct mammals. In the vicinity of Starunia there are many brine springs (Alexandrowicz, 2004; Duliński et al., 2005) whereas halite and potassium salt seams occur within the Lower Miocene salt-bearing Vorotyshcha Beds (Alexandrowicz, 2005). The salt-bearing clays host both the ozokerite veins and the rock-salt (halite) layers.

The rocks-salt was encountered for the first time in the "Nadzieja-3" well where seven 10-metre-thick salt beds were found at depths between 47.6 and 148.4 metres (Fig. 11). Both the halite and the potassium salt deposits were discovered before the World War II (Alexandrowicz, 2004, 2005) but were assessed after the war (Korin, 2005). However, according to historical sources, brine was exploited from shafts and wells in Starunia as early as in 1476 (Alexandrowicz, 2004). The Starunia salt work was closed at the break of 18th and 19th centuries and the same happened to salt-works in adjacent villages: Delatyn (1726), Gvizd (1798), Maniava (1831), Markova (1787), Molotkiv (1821) and Solotvina (1788) (Alexandrowicz, 2004).

There were two historical districts of rock-salt mining in Poland: (i) Cracovian, with salt mines in Wieliczka and Bochnia, in operation since at least 9th century and (ii) Ruthenian (recently in Ukraine) with royal salt mines in Tyrawa Solna, Stara Sól, Jasienica, Modrycz, Stebnik, Solec, Truskavets, Kalush and Solotvina belonging to the Duty of Halich and incorporated to Poland in 1349 , in operation probably since

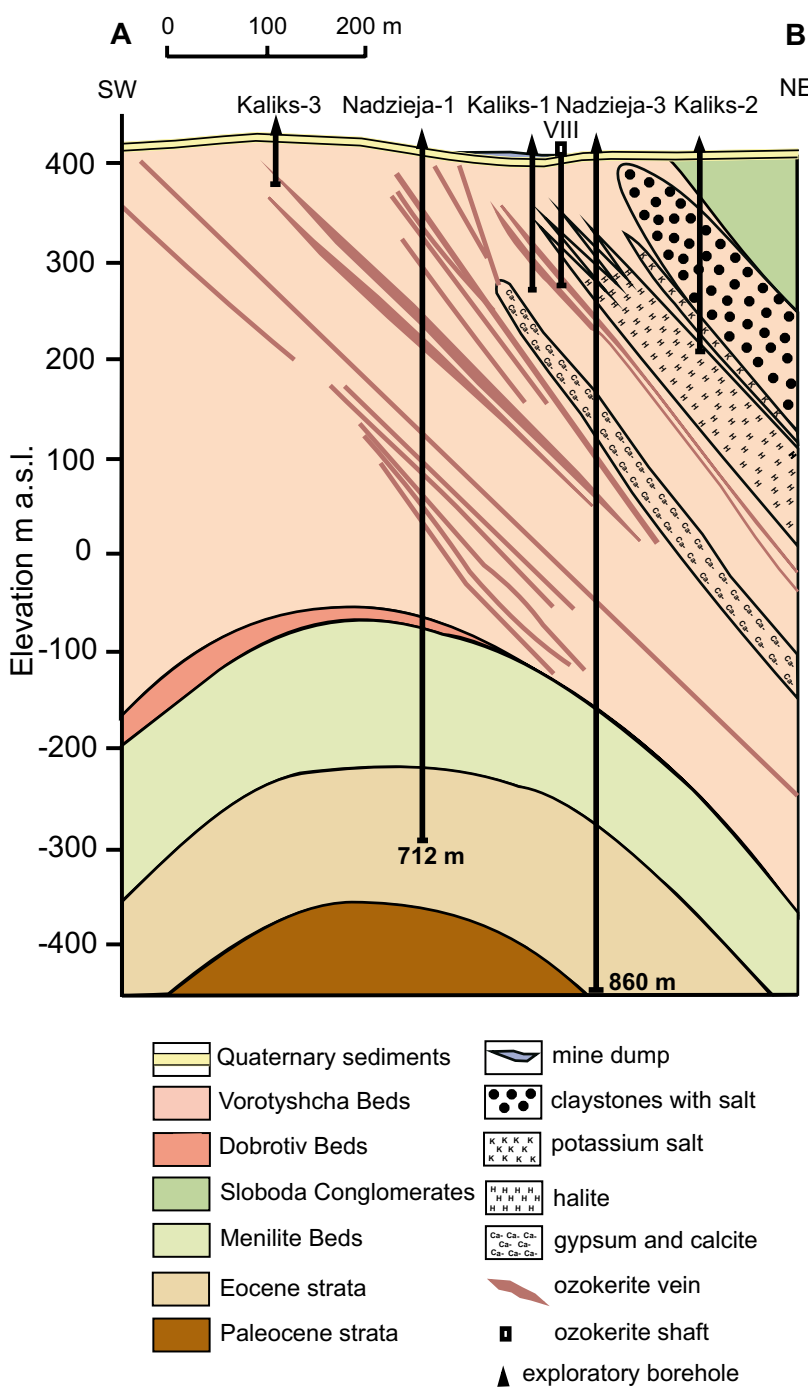

Fig. 11. Geological cross-section A-B through the Starunia ozokerite deposit, after Koltun et al. (2005). For location of section line see Fig. 2C • Przekrój geologiczny A-B przez złoże ozokerytu w Staruni, według Koltuna et al. (2005). Lokalizacja - patrz Fig. 2C

the Roman epoch (Windakiewicz, 1926, 1927; Hwałek, 1971). The rock-salt deposits in Wieliczka and Bochnia are hosted in the Miocene strata of the Zgłobice Unit whereas the rocksalt and potassium salt deposits in the eastern area occur in the Miocene strata of the Boryslav-Pokuttya and Stebnyk units of the inner part of the Carpahian Foredeep (Windakiewicz, 1926, 1927; Korin, 2005; Czapowski et al., 2009). The following, thematic volume of the "Geotourism" quarterly is devoted to the salt mines in both mentioned above salt mining districts: Cracovian (Wieliczka and Bochnia) (Wiewiórka et al., 2009) and Ruthenian (Kalush and Stebnyk) (Bukowski \& Czapowski, 2009), which will be the important parts of the future geotourist trail.

In the Polish part of the Carpathians both the brines and saline mineral waters encountered in the Outer (Flysch) Carpathians (e.g., Iwonicz, Poręba Wielka, Rabka, Rymanów, Sól, Ustroń) (Dowgiałło et al., 1969; Ciężkowski \& Rajchel, 2004) and in the Carpathian Foredeep (e.g., Jastrzębie, Kraków-Mateczny, Latoszyn) (Dowgiałło et al., 1969) are utilized in health resorts and bottled as table water. Similarly, before the World War II in the eastern Carpathians there existed 


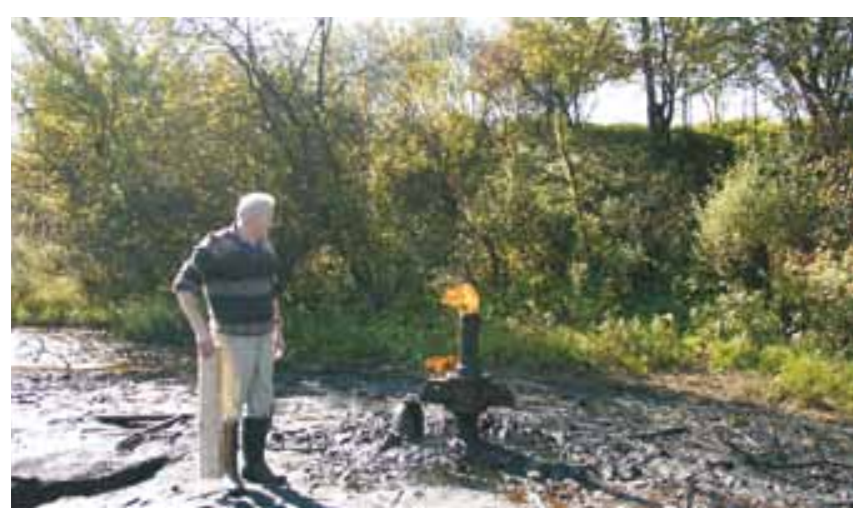

Fig. 12. The natural gas flame burning over the destroyed wellhead of the Nadzieja-1 well in Starunia. Phot. M.J. Kotarba • Płomień gazu ziemnego nad zniszczoną głowicą odwiertu Nadzieja-1 w Staruni. Fot. M.J. Kotarba

many resorts in which brines and saline mineral waters were utilized, e.g. Delatyn, Hrebeniv, Jaremche, Kosiv, Morshyn and Truskavets (Kapłon, 2004). Today, Truskavets is one of Ukrainian great health resorts, famous of its brine and sulphate-alkaline mineral springs. However, in the period between the World War I and II, Truskavets was one of the most popular spas in Poland (Radwański, 2009a). The spa itself was opened in 1836. Mineral water from the "Józia" spring (bicarbonate-alkaline) was bottled and sold as table water. The brine from the "Ferdynand" spring belonged to the most powerfull in Europe and water from the "Barbara" spring represented the "bitter" mineral waters. Especially famous was (and still is) the "Naftusia" mineral spring (Fig. 15) which supplies sulfur-scented, slightly saline water with distinct hydrocarbon (naphta) smell (Kapłon, 2004). Truskavets was also appreciated for specific, wooden architecture resembling that known from the Swiss and Austrian spas in the Alps. Unfortunately, during the Soviet Union times many such buildings were ruined or reconstructed and in the town center the ugly, multistorey houses were built. In the following, thematic volume of "Geotourism" resorts from the Eastern Carpathians are characterized: Truskavets in the Ukrainian part (Radwański, 2009a) and Iwonicz, and Rymanów in the Polish part (Radwański, 2009b) where brines and saline mineral waters are utilized for therapeutic purposes.

\section{The Starunia palaeontological site: history of discoveries}

In September, 1907 the new mining enterprise: "J. Campe and Co." started ozokerite mining operations at the new "Michajłowa-Dmytruk" Mine. As early as in October and November, 1907, during the deepening of No. IV shaft (later named "The Mammoth"), the incomplete carcasses of a mammoth and a woolly rhinoceros (so-called "the first rhinoceros from Starunia") with preserved soft tissues were found at depths of 12.5 and 17.6 metres, respectively. Both specimens were transferred to the Dzieduszycki's Family Natural History Museum in Lviv (present name: The Natural History Museum of the National Academy of Sciences of the Ukraine) (Kubiak \& Drygant, 2005; Chornobay \& Drygant, 2009).
Results of geological and palaeobotanical studies (Nowak et al., 1930) revealed that sediments excavated from No. IV shaft are secondary, which may suggest that both the mammoth and the "first" rhinoceros were discovered earlier and dumped into this shaft. According to Alexandrowicz (2004), this early discovery might have happened about 1887-1890.

In 1914, an extended monograph about the Starunia findings was published (Bayger et al., 1914), including 386 pages of text and separate atlas containing 67 tables. Discovery of the unique, mammoth and woolly rhinoceros fossils in No. IV shaft resulted in a keen interest in this palaeontological site and generated a will to continue the exploration.

Two documents issued in late November and early December, 1907 by eng. Franciszek Fałek, technical manager of the ozokerite mine in Starunia, were found in the State Archive in Lviv (Kotarba \& Stachowicz-Rybka, 2008). Both presented three very interesting variants of further exploration. Based upon available information, eng. Fałek assumed that Pleistocene sediments at depth interval from 14 to 25 metres had a high potential for further fossil fauna findings. It must be emphasized that the drillings completed in the years 20072008 proved that the bottom of Pleistocene sediments recently occurs at a maximum depth of 17 metres (Sokołowski et al., 2009; Kotarba, ed., 2009). According to eng. Fałek's ideas, the first variant ("a") of the Starunia excavation, most labour-consuming and expensive, included the digging of benched excavation down to 25 metres depth with the squared, $25 \times 25$ metres lowest bench and bank slopes at $40-60^{\circ}$. The volume of removed rock was estimated as about 20,000 cubic metres. The second, most interesting variant ("b"), proposed the cutting of 10-metres-long gallery at depths from 14 to 25 metres (Kotarba \& Stachowicz-Rybka, 2008). In the third variant ("c") two or more shafts should be sunk, distant from each other or, alternatively, small twin shafts should be made from which galleries should be cut in all directions at any depth. The small-scale underground works (only two days of excavations) were undertaken in 1911 under the supervision of Dr. W. Rogala (Alexandrowicz, 2004). Partly, the plans made in 1907 (variant "c") came into being during the next search, in 1929.

Exploration and scientific research in Starunia could not be continued earlier than after the World War I, in independent Poland, when a special National Culture Fund was established in 1928 by the Prime Minister, Marshall Joseph Piłsudski (Alexandrowicz, 2004). In 1929, under the auspices of the Polish Academy of Arts and Sciences (PAU), the Committee for Starunia Research was established and the new excavations were undertaken at the Starunia ozokerite mine. First, a new shaft (further called "the PAU shaft") was sunk under the supervision of a young geologist, Mr. Eugeniusz Panow. On October 23rd, 1929, in the gallery cut about 4.5 metres from No. IV shaft, at a depth of 12.5 metres an extraordinary, almost fully preserved carcass of a female woolly rhinoceros was found (later named "the second woolly rhinoceros from Starunia"). Moreover, in the same excavation, parts of the skeleton (without soft tissue) of "the third rhinoceros" were discovered (Stach, 1930) together with bones of "the fourth rhinoceros" (Kubiak, 2003). Soldiers from the Polish Army engineers' corps sunk a special recovery shaft $(4 \times 4 \mathrm{~m})$, 
A

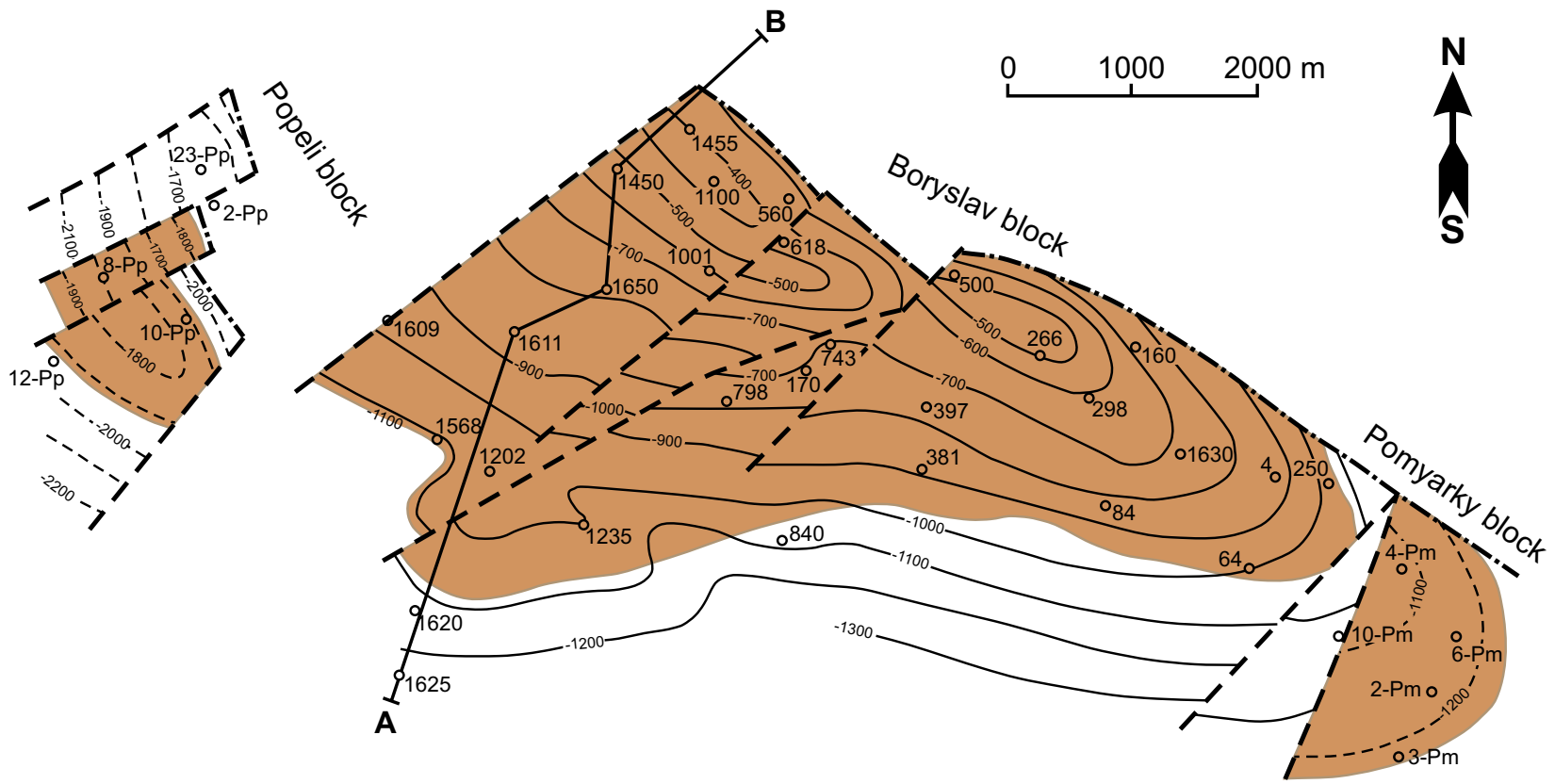

B

\section{A}

B
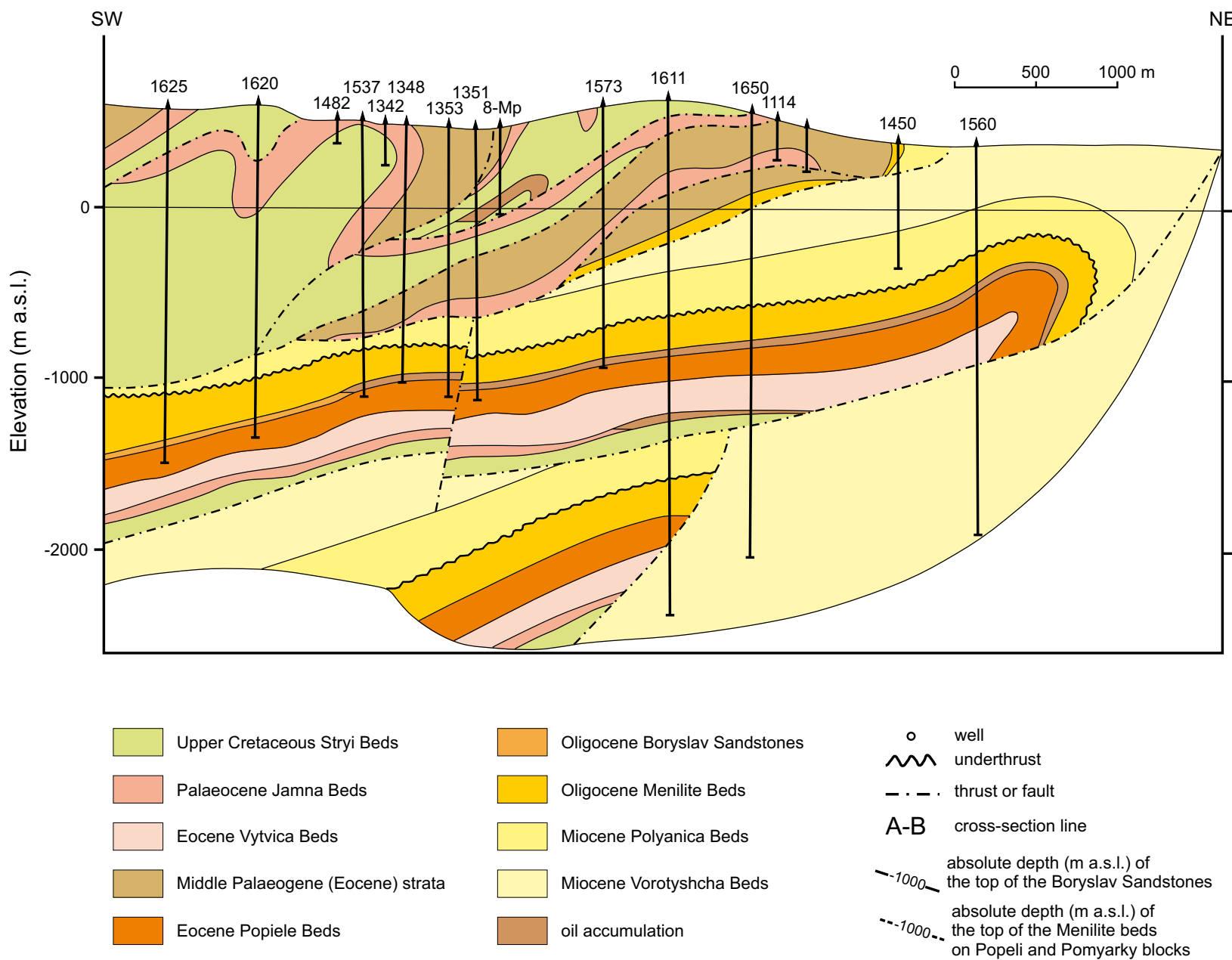

Fig. 13. (A) Structural map and (B) geological cross-section through the Boryslav oil deposit, after AOGFU (1998) • (A) Mapa strukturalna i (B) przekrój geologiczny przez złoże ropne Borysław, według AOGFU (1998) 


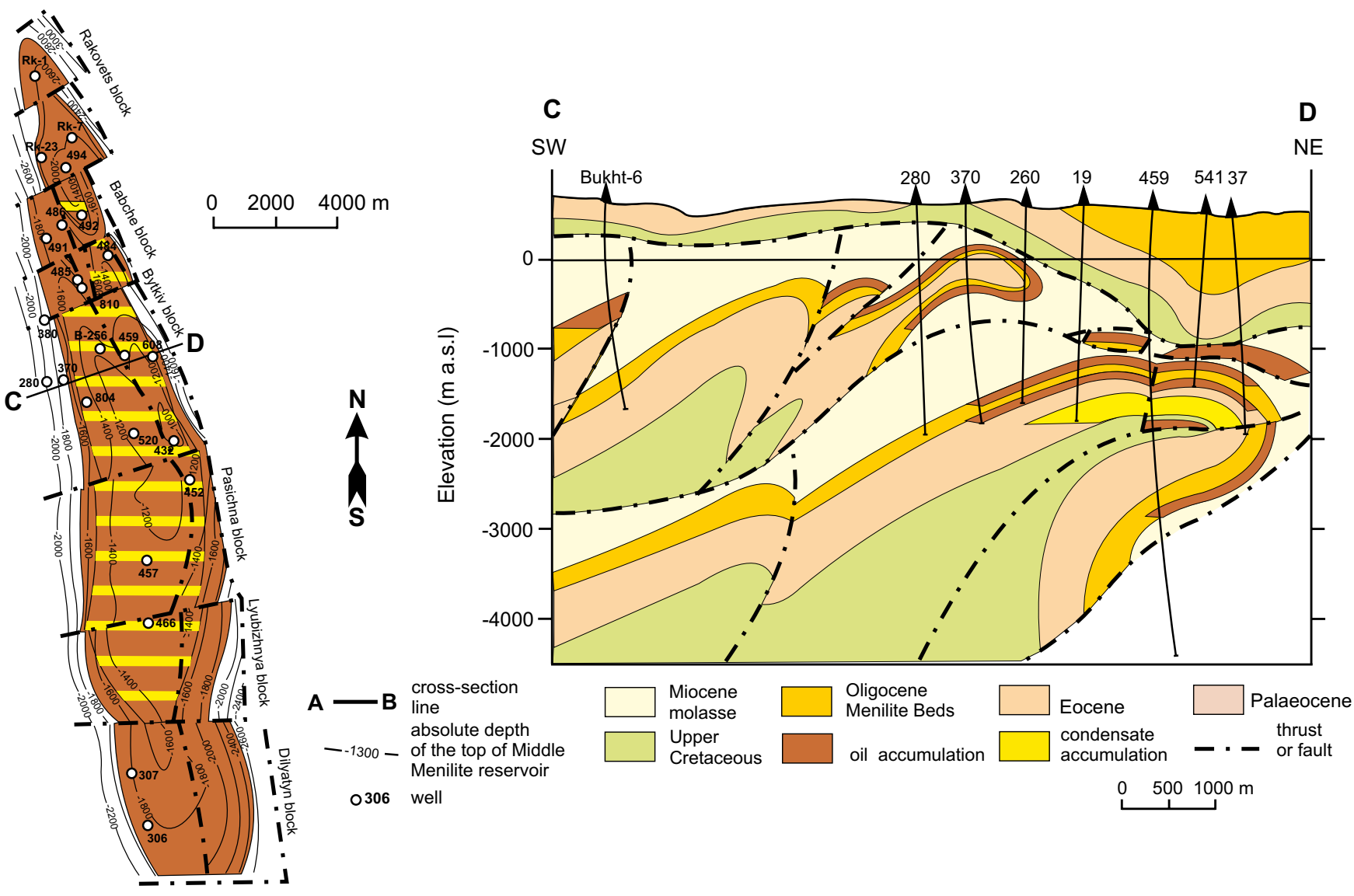

Fig. 14. (A) Structural map and (B) geological cross-section through the Bitkiv-Babche oil and gas/condensate deposit, after AOGFU (1998) - (A) Mapa strukturalna i (B) przekrój geologiczny przez złoże ropne i gazowo-kondensatowe Bitków-Babcze, według AOGFU (1998)

through which the carcass of the woolly rhinoceros was raised to the surface on December 17th, 1929. On December 22nd, 1929, the fossil was transported to Kraków, to the Natural History Museum of the Polish Academy of Arts and Sciences at 17, Sławkowska Street. In 1995, the fossil was moved to the Natural History Museum of the Institute of Systematics and Evolution of Animals, Polish Academy of Sciences, on 9, St. Sebastian Street in Kraków. Both museums in Kraków (Kubiak, 2009) and in Lviv (Chornobay \& Drygant, 2009) will be important sites of the future geoturist trail.

In the years 1931-1932, a small-scale underground exploration was run in Starunia around No. IV and the PAU shafts. The old sketch-map drawn by Mr. Panow (Alexandrowicz, 2004) shows old and new exploration workings together with localization of three shafts: No. IV ("Mammoth") from 1907, the PAU shaft, and the recovery shaft from 1929 (Fig. 2C).

In 1930, the monograph of "the second woolly rhinoceros" was published (Nowak et al., 1930). Moreover, since 1933, the Polish Academy of Arts and Sciences has been publishing the scientific series named "Starunia". The first five volumes were devoted to the studies of the Starunia site (Alexandrowicz, 2004).

\section{Interdisciplinary studies in the years 2004-2005 and 2006-2009}

In 2004, after more than a 70-years-long break, the interdisciplinary studies restarted in Starunia. The Society of
Research for Environmental Changes "Geosphere" in Kraków, in cooperation with the AGH University of Science and Technology in Kraków, the Ivano-Frankivsk National Technical University of Oil and Gas in Ivano-Frankivsk and the Institute of Geology and Geochemistry of Combustible Minerals of the National Academy of Sciences of Ukraine in Lviv, organized two scientific expeditions to Starunia. The objective was to analyze the geological structure and the specific sedimentary environment in which the Pleistocene mammals were found, and to assess the possibility of further findings of large fossil mammals.

In the years 2004-2005, the extended research program was carried out, including: sedimentological and dendrochronological studies, geophysical survey (D.C. resistivity, gravity and shallow temperature measurements), surface geochemical survey, microbiological studies, organic geochemical studies of hydrocarbon source rocks from outcrops and drill cores, and of oils and natural gases from deep accumulations and surface seeps, stable hydrogen and oxygen isotope analyses of surface and groundwaters, and radiocarbon datings of fauna remnants. The results were published in a monograph (Kotarba, ed., 2005), which contained 9 thematic papers presenting the results of field and laboratory studies in the Starunia area. The monograph included also additional 9 papers presenting the purposes, programs and comprehensive results of two Polish scientific expeditions to Starunia in 2004 and a spectrum of information related to historical and geological/geomorphological 

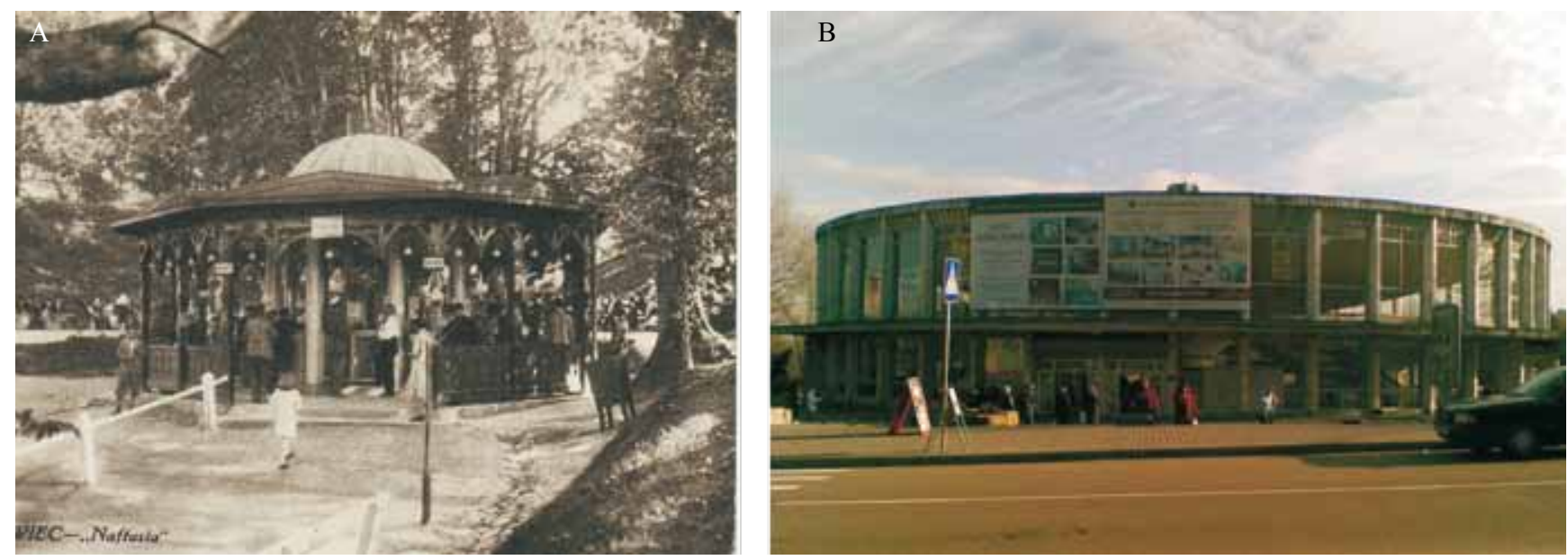

Fig. 15. Pump room of the "Naftusia" saline mineral water spring in Truskavets: (A) Polish postcard edited in 1930s, and (B) recent view. Phot. O.R. Stelmakh • Pijalnia wody mineralnej „Naftusia” w Truskawcu: (A) polska pocztówka z lat 1930-tych, (B) widok współczesny. Fot. O.R. Stelmakh

aspects of the area. Some of these were: the history of the Starunia palaeontological site and abandoned ozokerite mine; the history of petroleum exploration and production; geological setting and occurrence of oil and gas deposits; characterization of the Miocene salt-bearing Vorotyshcha Beds, and geomorphological/neotectonic features of the area. Some related problems were also presented and discussed: the archaeological sites in the Starunia, the collections of fossils in natural history museums in Lviv and in Kraków connected with the discoveries of Pleistocene mammoth and woolly rhinoceroses in Starunia, and the concept of an "Ice -Age park" in the Starunia area as an ecological and tourist centre. The results of interdisciplinary studies carried out in the years 2004-2005 around the Starunia palaeontological site led to preliminary contouring of a Pleistocene water reservoir ("palaeomarsh"), into which large mammals sunk and in which their bodies were subsequently preserved (Kotarba, ed., 2005; Kotarba et al., 2008).

In the years 2006-2009 the Faculty of Geology, Geophysics and Environmental Protection at the AGH University of Science and Technology in Kraków organized the new interdisciplinary studies in Starunia, in cooperation with scientists from the Institute of Botany of the Polish Academy of Sciences in Kraków and the Department of Microbiology of the University of Agriculture in Kraków. The results were published as a thematic volume of the Annales Societatis Geologorum Poloniae in which 18 papers present the results of field and laboratory studies completed by Polish scientists (Kotarba, ed., 2009). The interdisciplinary studies were run by eleven thematic working groups on: Quaternary lithology and sedimentology, palaeobotany (palynology and analysis of macrofossils), botany (analysis of halophytes), palaeozoology (malacological analysis), radiocarbon dating, microbiology, surface and nearsurface geochemistry, organic geochemistry (bitumen content and its fractions, biomarkers and stable carbon isotopes) and inorganic geochemistry (chloride ion analysis), geoelectric survey (DC resistivity soundings, electromagnetic terrain conductivity measurements, resistivity imaging, penetrometer -based resistivity profiling and azimuthal pole-dipole DC resistivity soundings) and microgravimetric survey.
The results of these studies enabled the authors to recognize the details of geological setting and the sedimentary environment of Quaternary deposits which hosted the Pleistocene fossils, and to identify the most favourable area of about 1,000 square metres (Fig. 2C), where potential exists for the new findings of woolly rhinoceroses, mammoths and, eventually, also human bodies within the Pleistocene sediments in Starunia. The bottom of the mud complex of Pleistocene sediments of the thickness exceeding $2 \mathrm{~m}$ occurs at the depth interval of 4.5 to $7.5 \mathrm{~m}$ (Kotarba, 2009; Kotarba, ed., 2009; Kotarba et al., 2009; Sokołowski et al., 2009). It is well-known from archaeological records that in the Pleistocene at least 17 settlements of ancient hunters have existed in Starunia and vicinity (Matskevyj, 2005). Hence, it is reasonable to expect that also humans might have sunk into the marsh and their bodies might have been preserved.

\section{Conclusions}

The thematic volume of the "Geotourism" quarterly was issued on the occassion of 80th anniversary of almost fully preserved woolly rhinoceros finding, made by Polish geologists at the ozokerite mine in Starunia, in 1929. The soft tissue of the animal was preserved due to saturation with brine and oil. The rhinoceros specimen is recently exhibited at the Museum of Natural History of the Polish Academy of Sciences in Kraków. Previously, in 1907, at the same mine the "first woolly rhinoceros" and the mammoth remnants were found. These are exhibited at the Natural History Museum of the National Academy of Sciences of Ukraine in Lviv.

Both museums in Kraków and in Lviv together with other sites in the Polish and Ukrainian Carpathians related to the occurrence of ozokerite (earth wax), salt, brine and oil are the backbone of the Ukrainian-Polish trans-border geoturist trail "Traces of large extinct mammals, earth wax, oil and salt: Starunia - Kalush - Boryslav region Lviv - Bóbrka - Krosno region - Bochnia - Wieliczka Kraków". 


\section{Streszczenie}

\section{Stanowisko paleontologiczne w Staruni i idea utworzenia ukraińsko-polskiej trasy geoturystycznej „Śladami olbrzymich wymarlych ssaków, wosku ziemnego, ropy naftowej i soli: od Staruni do Krakowa"}

\section{Maciej J. Kotarba}

Odkrycie wielkich ssaków plejstoceńskich, sprzed 40-35 tys. lat (Kuc et al., 2005; Kuc et al., 2011), w kopalni ozokerytu w Staruni (region karpacki, Ukraina) było spektakularnym wydarzeniem naukowym w skali światowej. Pierwszego odkrycia dokonano w 1907 r. gdy znaleziono szczątki mamuta i nosorożca włochatego. W roku 1929 Polska Akademia Umiejętności zorganizowała ekspedycję naukową, podczas której natrafiono na kolejny okaz nosorożca włochatego, leżący na głębokości 12.5 $\mathrm{m}$. Jest to jedyny na świecie, zachowany prawie w całości przedstawiciel tego gatunku wymarłego ok. 11 tys. lat temu (Fig. 1). Niezwykłe i wyjątkowe zakonserwowanie tkanek miękkich dokonało się w naturalny sposób dzięki nasyceniu iłów plejstoceńskich ropą naftową oraz solanką. Ponadto odkryto wtedy szczątki jeszcze dwóch nosorożców włochatych. Okazy znalezione w roku 1907 znajdują się w Narodowym Muzeum Przyrodniczym Akademii Nauk Ukrainy (byłe Muzeum im. Dzieduszyckich) we Lwowie (Chornobay \& Drygant, 2009), a te odkryte w roku 1929 sa przechowywane w Muzeum Przyrodniczym w Krakowie oraz w Zakładzie Paleozoologii Polskiej Akademii Nauk w Krakowie (Kubiak, 2009).

W Staruni znajduje się również nieczynna kopalnia ozokerytu (Fig. 2), wulkany błotne, wycieki powierzchniowe ropy naftowej i gazu ziemnego i stanowiska archeologiczne (Adamenko et al., 2009). Miejscowość ta położona jest w malowniczej scenerii Karpat Ukraińskich, widoczne są z niej zaśnieżone przez większą część roku ponad dwutysięczne szczyty Gorganów (Fig. 3).

Te trzy miejscowości: Starunia, niewielka wioska ukraińska, w której planuje się utworzenie geoparku i centrum muzealniczo -turystycznego (Adamenko et al., 2009) oraz dwa duże historyczne miasta Lwów i Kraków (Fig. 4), ściśle związane z tym niezwykle rzadkim znaleziskiem (Chornobay \& Drygant, 2009; Kubiak, 2009) będą stanowić główne, węzłowe miejsca planowanej ukraińsko-polskiej trasy geoturystycznej „Śladami olbrzymich wymarłych ssaków, wosku ziemnego, ropy naftowej i soli: od Staruni do Krakowa".

Karpaty polskie i ukraińskie reprezentują środkową część alpejskiego łuku Karpat, który rozpościera się od Wiednia do Żelaznych Wrót w Rumunii (Fig. 4). Polskie i ukraińskie Karpaty zewnętrzne (fliszowe) stanowią zewnętrzną cześć młodej alpejskiej strefy orogenicznej o strukturze płaszczowinowonasuwczej, złożoną z licznych kompleksów piaskowcowych i łupkowych (mułowce i iłowce) w jednostkach tektonicznych skolskiej (skibowej na Ukrainie), śląskiej (krośnieńskiej na Ukrainie), podśląskiej, dukielskiej, grybowskiej, magurskiej, porkuleckiej, rachowskiej, marmaroszeńskiej i czarnohorskiej
(Fig. 4). Zapadlisko przedkarpackie dzieli się na dwa baseny: zewnętrzny i wewnętrzny. Sfałdowane jednostki zgłobicka, stebnicka (na Ukrainie zwana samborską) i borysławsko-pokucka z sedymentologicznego punktu widzenia należą do wewnętrznej części zapadliska przedkarpackiego, natomiast tektonicznie zostały sfałdowane razem z jednostkami Karpat zewnętrznych. Jednostka zgłobicka występuję tylko w Polsce, natomiast jednostka borysławsko-pokucka na Ukrainie. Basen zewnętrzny (= jednostka bilcze-wolicka na Ukrainie) jest wypełniony utworami miocenu autochtonicznego. Poglądowe przekroje geologiczne i profile litostratygraficzne poszczególnych jednostek tektonicznych Karpat zewnętrznych i zapadliska przedkarpackiego w Polsce i na Ukrainie są przedstawione odpowiednio na Fig. 5 i 6 oraz na Fig. 7 i 8. W rejonie Staruni osady czwartorzędowe zalegają na utworach jednostki borysławsko-pokuckiej (Fig. 2). Pierwsza mapa geologiczna rejonu Staruni została wykonana przez R. Zubera w roku 1888 i uzupełniona przez J. Łomnickiego (Fig. 9).

Ozokeryt, zwany również woskiem ziemnym jest mieszaniną stałych węglowodorów nasyconych i był używany: w medycynie, do produkcji świec, jako izolator oraz składnik smarów. Zapotrzebowanie na ozokeryt znacznie wzrosło pod koniec XIX w., kiedy został on wykorzystany jako materiał izolacyjny podmorskiego kabla międzykontynentalnego, który był wtedy kładziony na dnie Oceanu Atlantyckiego między Europą a Ameryką Północną. Największe na świecie złoża ozokerytu znajdują się w ukraińskiej części zapadliska przedkarpackiego. Niewielkie złoża występują w Uzbekistanie i Turkmenistanie, a mniejsze nagromadzenia w USA, Chinach, Birmie, Hiszpanii, Włoszech, Egipcie i Rumunii. W regionie karpackim występują one głównie w dolnomioceńskich warstwach worotyszczańskich jednostki borysławsko-pokuckiej. Złoża Borysław, największe w Karpatach, odkryto w 1855 r. Eksploatację następnie rozpoczęto w Wolance (1957), Staruni (1868), Dźwiniaczu (1870), a kilka lat później w Pomiarkach koło Truskawca (Fig. 4).

W roku 1886 w staruńskich kopalniach „Michajłowa” i „Dmytruk” było czynnych 109 szybów wydobywczych należących do kilkunastu właścicieli. W 1907 r., kopalnie te zostały połączone i przejęte przez firmę górniczą "J. Campe and Co." z Hamburga. Na Fig. 10 przedstawiono lokalizację szybów i odwiertów na tej kopalni w latach 1886-1942. Złoże ozokerytu w Staruni występuje na głębokości od 10 do około $500 \mathrm{~m}$ poniżej powierzchni. W obrębie warstw worotyszczańskich, obok żył, gniazd i pokładów ozokerytu najczęściej o grubości od 2 do $30 \mathrm{~cm}$ (rzadko kilka metrów), występują także pokłady soli kamiennej i potasowej (Fig. 11). W obrębie struktury antyklinalnej istniało nagromadzenie węglowodorów, które migrowały ku powierzchni przez układ uskoków i szczelin. W wyniku tego procesu wytrącał się w nich ozokeryt. W 1929 r., w otworze Nadzieja-1 stwierdzono niewielkie nagromadzenie ropy naftowej i gazu ziemnego, które zakończyło się po kilkunastu latach eksploatacji. Dzisiaj ze zniszczonej głowicy tego odwiertu wydobywa się gaz ziemny, który często pali się wysokim płomieniem (Fig. 12). Ropa naftowa i gaz ziemny, a także solanka związana z pokładami soli, migrowały przez uskoki i szczeliny, nasycały osady plejstoceńskie oraz tworzyły i tworzą do dzisiaj na powierzchni wulkany błotne i ,oczka ropne” oraz słone źródła. Miąższość utworów czwartorzędowych sięga maksymalnie 17 metrów. Eksploatację ozokerytu 
w Staruni zakończono w 1960 r. Ocenia się, że w latach 1868 - 1960 wydobycie ozokerytu ze złoża Starunia wyniosło ok. 5 tys. ton, a jego zasoby tylko na jednym polu „Nadzieja” wynoszą ok. 400 tys. ton. Struktury fałdowe w okolicy Staruni są bardziej szczelne i zawierają akumulacje złożowe ropy naftowej i gazu ziemnego: Bitków-Babcze (Bytkiv-Babche), Hwozd (Gvizd), Południowy Hwozd (Pivdenny Gvizd), Markowa (Markova), Monastyrczany (Monastyrchany), Pniów (Pniv) i Pasieczna (Pasichna) (Fig. 2A). Skałą macierzystą dla tych węglowodorów były oligoceńskie łupki menilitowe.

Region Karpat polskich i ukraińskich jest jednym z najstarszych basenów naftowych na świecie. Wydobycie ropy naftowej rozpoczęto w 1854 r., a gazu ziemnego w 1920 r. Największe złoże ropy naftowej, ozokerytu i gazu kondensatowego odkryto w Borysławiu (Fig. 13). Drugim co do wielkości w Karpatach ukraińskich jest złoże ropy naftowej i gazu kondensatowego Bitków-Babcze (Fig. 14). W regionie karpackim w Polsce znajdowały się dwa historyczne obszary wydobycia soli: (i) podkrakowski, złożony z żup w Wieliczce i Bochni, działający co najmniej od XI wieku oraz (ii) ruski, dzisiaj na terenie Ukrainy, składający się z żup królewskich w Tyrawie Solnej, Starej Soli, Jasienicy, Modryczu, Stebniku, Solcu, Truskawcu, Kałuszu i Sołotwinie.

W latach 2004-2005, po długiej przerwie, wznowione zostały badania naukowe w Staruni zorganizowane przez Towarzystwo Badania Przemian Środowiska „Geosfera” przy współudziale Akademii Górniczo-Hutniczej w Krakowie, Uniwersytetu Technicznego Ropy i Gazu w Iwanofrankiwsku oraz Instytutu Geologii i Geochemii Surowców Energetycznych Narodowej Akademii Nauk Ukrainy we Lwowie. Wykonano badania geologiczne, hydrogeologiczne, geofizyczne, geochemiczne i mikrobiologiczne. Ich celem było określenie budowy geologicznej i specyficznego środowiska utworów czwartorzędowych, zawierających dotychczas znalezione szczątki ssaków plejstoceńskich. Wyniki badań wydano w formie monografii, która składa się z 18 artykułów (Kotarba, ed., 2009). W latach 2006-2009 badania były kontynuowane przez Wydział Geologii, Geofizyki i Ochrony Środowiska
Akademii Górniczo-Hutniczej w Krakowie przy współpracy Instytutu Botaniki Polskiej Akademii Nauk oraz Katedry Mikrobiologii Uniwersytetu Rolniczego w Krakowie. Wyniki interdyscyplinarnych badań litologicznych, sedymentologicznych, paleobotanicznych, paleozoologicznych (malakologicznych), datowania radiowęglowego, geofizycznych (geoelektryczne i mikrograwimetryczne), geochemii powierzchniowej, geochemii organicznej, geochemii nieorganicznej i mikrobiologicznych zostały opublikowane jako numer tematyczny Annales Societatis Geologorum Poloniae zawierający 18 artykułów (Kotarba, ed., 2009). Rozpoznanie warunków litofacjalnych i sedymentologicznych osadów plejstoceńskich nasyconych ropą naftową i solanką umożliwiło wyznaczenie obszaru o powierzchni ok. 10 ha (Fig. 2C), w którym istnieją najkorzystniejsze warunki odkrycia nowych okazów mamutów i nosorożców włochatych, a nawet szczątki żyjącego wtedy człowieka. W okolicy Staruni znajduje się 17 stanowisk archeologicznych starych ludów łowieckich (Matskevyj, 2005), można więc przypuszczać, że ludzie polujący na wielkie ssaki, mogli się utopić w bagnistym terenie nasyconym solanką i ropą naftową, a ich ciała mogły ulec zakonserwowaniu.

Do trasy geoturystycznej zostaną też włączone miejsca związane z występowaniem ozokerytu, soli, solanki i ropy naftowej, a więc czynnikami, które spowodowały zakonserwowanie tych olbrzymich wymarłych ssaków: historyczne kopalnie Wieliczka i Bochnia (Wiewiórka et al., 2009) oraz Kałusz i Stebnik (Bukowski \& Czapowski, 2009), polskie uzdrowiska - Iwonicz-Zdrój i Rymanów-Zdrój (Radwański, 2009b) oraz najsłynniejsze uzdrowisko ukraińskie - Truskawiec (Fig. 15) (Radwański, 2009a); jedno z najdawniej eksploatowanych na świecie złóż ropy naftowej w Bóbrce, w której znajduje się Skansen - Muzeum Przemysłu Naftowego i Gazowniczego im. Ignacego Łukasiewicza (Radwański, 2009b) oraz największe w Karpatach złoże ropy naftowej i ozokerytu Borysław (Radwański, 2009a). Za realizacją projektu utworzenia ukraińsko-polskiej trasy geoturystycznej przemawiaja walory geologiczne, przyrodnicze i kulturowe Karpat polskich i ukraińskich.

\section{References (Literatura)}

Adamenko, O.M., Stelmakh, O.R., Zinchuk, M.S. \& Kotarba, M.J., 2005a. History of petroleum exploration in the Starunia area, fore-Carpathian region, Ukraine. In: Kotarba, M.J. (Ed.), Polish and Ukrainian geological studies (2004-2005) at Starunia - the area of discoveries of woolly rhinoceroses. Polish Geological Institute and Society of Research an Environmental Changes "Geosphere”, Warszawa-Kraków: 53-60.

Adamenko, O.M., Krizhanivskiy, E.I., Vekeryk, V.I., Stelmakh, O.P., Mischenko, L.V., Zorina, N.O., Zorin, D.O. \& Ambrozyak, M.V., 2005b. A concept of an international "Ice-Age Geopark" as an ecological-tourist center in Starunia former ozokerite mine, fore-Carpathian region, Ukraine. In: Kotarba, M.J. (Ed.), Polish and Ukrainian geological studies (2004-2005) at Starunia - the area of discoveries of woolly rhinoceroses. Polish Geological Institute and Society of Research an Environmental Changes "Geosphere", Warszawa-Kraków: 205-210.

Adamenko, O.M., Stelmakh, O.R., Zorin, D.O. \& Radlovska, K.O., 2009. Idea of the ecological and geological tourist centre in Starunia (ForeCarpathian region, Ukraine). Geoturystyka, This volume.

Alexandrowicz, S.W., 2004. Starunia and the Quaternary research in the tradition and initiatives of the Polish Academy of Arts and Sciences (in Polish, English abstract). Studia i materiały do dziejów Polskiej Akademii Umiejętności. Polish Academy of Arts and Sciences, Kraków, 3: $261 \mathrm{pp}$.

Alexandrowicz, S.W., 2005. The history of Starunia - a palaeontologic site and old ozokerite mine. In: Kotarba, M.J. (Ed.), Polish and Ukrainian geological studies (2004-2005) at Starunia - the area of discoveries of woolly rhinoceroses. Polish Geological Institute and Society of Research an Environmental Changes "Geosphere", Warszawa-Kraków: 21-36.

AOGFU, 1998. Atlas of oil and gas fields of Ukraine (Atlas naftovykh i gazovykh rodovysch Ukrainy). V. Fedyshyn et al. (Eds.). Lviv, Ukrainian Oil and Gas Academy, 5, 710 pp. (In Ukrainian and English)

Bayger, J.A., Hoyer, H., Kiernik, E., Kulczyński, W., Łomnicki, M., Łomnicki, J., Mierzejewski, W., Niezabitowski, E., Raciborski, M., Szafer, W. \& Schille, F., 1914. Wykopaliska Staruńskie. Muzeum im. Dzieduszyckich we Lwowie, 15: 386 pp. (In Polish only)

Bojko, G. \& Sozański, J., 2004. Ozokeryt. In: J. Raczkowski, J. Zarubin (Eds.), Nafta i gaz Podkarpacia, Zarys historii. Oil and Gas Institute, Kraków, Naukova Dumka, Kyiv: 345-360. (In Polish and Ukrainian)

Bukowski, K. \& Czapowski, G., 2009. Salt geology and mining traditions: Kalush and Stebnyk mines (Fore-Carpathian region, Ukraine). Geoturystyka, This volume.

Chornobay, Y.M. \& Drygant, D.M., 2009. The Starunia collections in the Natural History Museum of the National Academy of Sciences of Ukraine in Lviv. Geoturystyka, This volume.

Ciężkowski, W. \& Rajchel, L., 2004. Wody lecznicze polskich Sudetów i Karpat. In: Wójcik, W.A. (Ed.), Uzdrowiska górskie w Polsce. Centralny Ośrodek Turystyki Górskiej PTTK, Kraków: 9-36. (In Polish only)

Cieszkowski, M., Ślączka, A. \& Wdowiarz, S., 1985. New data on structure of the Flysch Carpathians. Przegląd Geologiczny, 33: 313-333.

Czapowski, G., Bukowski, K. \& Poborska-Młynarska, K., 2009. Miocene 
rock and potash salts of West Ukraine. Field geological-mining seminar of the Polish Salt Mining Society. Geologia (Przegląd Solny 2009), Wyd. AGH, Kraków, 35 (3): 479-490. (In Polish, English summary)

Dowgiałło, J., Karski, A. \& Potocki, I., 1969. Geologia surowców balneologicznych. Wydawnictwo Geologiczne, Warszawa. 296 pp. (In Polish only)

Duliński, M., Różański, K. \& Kotarba, M.J., 2005. Isotopic and chemical composition of surface and groundwaters in the Starunia area, foreCarpathian region, Ukraine. In: Kotarba, M.J. (Ed.), Polish and Ukrainian geological studies (2004-2005) at Starunia - the area of discoveries of woolly rhinoceroses. Polish Geological Institute and Society of Research an Environmental Changes “Geosphere”, Warszawa-Kraków: 187-194.

Hwałek, S., 1971. Górnictwo soli kamiennych i potasowych, Wyd. Śląsk, Katowice, 336 pp. (In Polish only)

Kapłon, 2004. Uzdrowiska i stacje klimatyczne na Kresach Wschodnich II Reczypospolitej do 1939 roku. In: Wójcik, W.A. (Ed.), Uzdrowiska górskie w Polsce. Centralny Ośrodek Turystyki Górskiej PTTK, Kraków: 161-170. (In Polish only)

Karnkowski, P., 1999. Oil and gas deposits in Poland: The Geosynoptics Society "GEOS", Krakow, 380 pp.

Koltun, Y.V., Adamenko, O.M., Kotarba, M.J., Dudok, I.V., Pavluk, M.I., Burzewski, W. \& Stelmakh, O.R., 2005. Geological setting and petroleum occurrence of the Starunia area, fore-Carpathian region, Ukraine. In: Kotarba, M.J. (Ed.), Polish and Ukrainian geological studies (20042005) at Starunia - the area of discoveries of woolly rhinoceroses. Polish Geological Institute and Society of Research an Environmental Changes "Geosphere", Warszawa-Kraków: 61-77.

Korin, S.S., 2005. Miocene salt-bearing Vorotyshcha Beds in the Starunia area, fore-Carpathian region, Ukraine. In: Kotarba, M.J. (Ed.), Polish and Ukrainian geological studies (2004-2005) at Starunia - the area of discoveries of woolly rhinoceroses. Polish Geological Institute and Society of Research an Environmental Changes "Geosphere", Warszawa-Kraków: 79-86.

Kotarba, M.J., 1998. Composition and origin gaseous hydrocarbons in the Miocene strata of the Polish part of the Carpathian Foredeep. Przegląd Geologiczny, 46: 751-758.

Kotarba, M.J., 2002. Composition and origin of hydrocarbons saturating the remnants of rhinoceros from Starunia, the Ukrainian Carpathians. (Polish, English abstract). Przegląd Geologiczny, 50 (6): 531-534.

Kotarba, M.J. (Ed.), 2005. Polish and Ukrainian geological studies (20042005) at Starunia - the area of discoveries of woolly rhinoceroses. Polish Geological Institute and Society of Research an Environmental Changes "Geosphere", Warszawa-Kraków, 218 pp.

Kotarba, M.J., 2009. Interdisciplinary studies at Starunia palaeontological site and vicinity (Carpathian region, Ukraine) in the years 2006-2009: previous discoveries and research, purposes, results and perspectives. Annales Societatis Geologorum Poloniae, 79: 219-241.

Kotarba, M.J. (Ed.), 2009. Interdisciplinary studies (2006-2009) at Starunia (Carpathian region, Ukraine) - the area of discoveries of woolly rhinoceroses. Annales Societatis Geologorum Poloniae, 79 (3): 217-480.

Kotarba, M.J. \& Koltun, Y.V., 2006. The origin and habitat of hydrocarbons of the Polish and Ukrainian Parts of the Carpathian Province. In: Golonka, J. \& Picha, F.J (Eds.), The Carpathians and their foreland: geology and hydrocarbon resources. American Association of Petroleum Geologists, Memoir 84: 395-442.

Kotarba, M.J. \& Koltun, Y.V., 2011. Origin of natural gases accumulated in the Miocene strata and the Mesozoic basement of the western part of the Ukrainian Carpathian Foredeep. Annales Societatis Geologorum Poloniae, 79. (In press)

Kotarba, M.J. \& Stachowicz-Rybka, R., 2008. Wyjątkowe stanowisko paleontologiczne i środowisko osadów plejstoceńskich, w których znaleziono nosorożce włochate w Staruni (Karpaty Wschodnie). Przegląd Geologiczny, 56 (6): 442-452. (In Polish only)

Kotarba, M.J., Dzieniewicz, M., Mościcki, W.J. \& Sechman, H., 2008. Unique Quaternary environment for discoveries of woolly rhinoceroses in Starunia, fore-Carpathian region, Ukraine: Geochemical and geoelectric studies. Geology, 36 (7): 567-570.

Kotarba, M. J., Więcław, D., Toboła, T., Zych, H., Kowalski, A. \& Ptak, S., 2009. Bitumen and salt contents within the Quaternary sediments at Starunia palaeontological site and vicinity (Carpathian region, Ukraine). Annales Societatis Geologorum Poloniae, 79: 447-461.

Krobicki, M., Golonka, J., Cyran, K., Leśniak, T., Strzeboński, P. \& Toboła, T., 2008. Field trip. Marginal part of Western Carpathians and Carpathian Foredeep. In: Słomka, T. (Ed.), 4th International Conference
Geotour 2008 "Geotourism and Mining Heritage". 26-28 June 2008, Kraków, Poland. AGH University of Science and Technology, Faculty of Geology, Geophysics and Environmental Protection, IAGt - International Asociation for Geotourism: 81-111.

Kubiak, H., 2003. Nosorożce i mamut ze Staruni. Prace Komisji Paleogeografii Czwartorzędu PAU, 1: 19-20. (In Polish only)

Kubiak, H., 2009. The Starunia collections in the Institute of Systematics and Evolution of Animals, Polish Academy of Sciences in Kraków. Geoturystyka, This volume.

Kubiak, H. \& Drygant, D.M., 2005. The Starunia collections in Lviv and Kraków natural history museums and history of palaeontological studies. In: Kotarba, M.J. (Ed.), Polish and Ukrainian geological studies (20042005) at Starunia - the area of discoveries of woolly rhinoceroses. Polish Geological Institute and Society of Research an Environmental Changes "Geosphere", Warszawa-Kraków: 37-44.

Kuc, T., Różański, K., Goslar, T., Kubiak, H. \& Kotarba, M.J., 2005. Radiocarbon dating of remnants of woolly rhinoceroses and mammoth from Starunia, fore-Carpathian region, Ukraine. In: M.J. Kotarba (Ed.), Polish and Ukrainian geological studies (2004-2005) at Starunia - the area of discoveries of woolly rhinoceroses. Polish Geological Institute and Society "Geosphere”, Warszawa-Kraków: 195-204.

Matskevyj, L.G., 2005. Archaeological sites in the Starunia area, fore-Carpathian region, Ukraine. In: Kotarba, M.J. (Ed.), Polish and Ukrainian geological studies (2004-2005) at Starunia - the area of discoveries of woolly rhinoceroses. Polish Geological Institute and Society of Research an Environmental Changes "Geosphere”, Warszawa-Kraków: 45-51.

Nowak, J., Panow, E., Tokarski, J., Szafer, W. \& Stach, J. (Eds.), 1930. The second woolly rhinoceros (Coelodonta antiquitatis Blum.) from Starunia, Poland. Bulletin International de l'Académie Polonaise des Sciences et des Lettres de Cracovie, Ser. B, Cracovie: 1-49.

Oszczypko, N., 1997. The early-middle Miocene Carpathian peripherial foreland basin (Western Carpathians, Poland). Przegląd geologiczny, 45 (10/2): 1054-1063.

Oszczypko, N., Krzywiec, P., Popadyuk, I. \& Peryt, T., 2006. Carpathian Foredeep Basin (Poland and Ukraine): its sedimentary, structural, and geodynamic evolution. In: Golonka, J. \& Picha, F.J. (Eds.), The Carpathians and their foreland: geology and hydrocarbon resources. American Association of Petroleum Geologists, Memoir 84: 261-318.

Przyrowski, Z., 1961. Światło z Ziemi. Wyd. Nasza Księgarnia, Warszawa, 173 pp. (In Polish only)

Radwański, A.B., 2009a. The oil and ozokerite mine in Boryslav and historical monuments of petroleum and salt industries in its vicinity (ForeCarpathian region, Ukraine). Geoturystyka, This volume.

Radwański, A.B., 2009b. The Ignacy Łukasiewicz Memorial Museum of Oil and Gas Industry in Bóbrka and historical monuments of petroleum and salt industries in the vicinity of Krosno (the Polish Outer Carpathians). Geoturystyka, This volume.

Ślączka, A. \& Kamiński, M.A. 1998. A Guidebook to excursions in the Polish Flysch Carpathians. Special Publication no. 6, Grzybowski Foundation, Kraków, 171 pp.

Ślączka, A., Krugłov, S., Golonka, J., Oszczypko, N. \& Popadyuk, I., 2006. Geology and hydrocarbon resources of the Outer Carpathians, Poland, Slovakia and Ukraine. In: Golonka, J. \& Picha, F.J. (Eds.), The Carpathians and their foreland: geology and hydrocarbon resources. American Association of Petroleum Geologists, Memoir 84: 221-258.

Sokołowski, T., Stachowicz-Rybka, R. \& Woronko, B., 2009. Upper Pleistocene and Holocene deposits at Starunia palaeontological site and vicinity (Carpathian region, Ukraine). Annales Societatis Geologorum Poloniae, 79: 255-278.

Stach, J., 1930. The second rhinoceros from the diluvial strata of Starunia. In: Nowak, J., Panow, E., Tokarski, J., Szafer, W. \& Stach, J. (Eds.), The second woolly rhinoceros (Coelodonta antiquitatis Blum.) from Starunia, Poland. Bulletin International de l'Académie Polonaise des Sciences et des Lettres de Cracovie, Ser. B, Cracovie: 21-47.

Wiewiórka, J., Charkot, J., Dudek, K. \& Gonera, M., 2009. Historic salt mines in Wieliczka and Bochnia. Geoturystyka, This volume.

Windakiewicz, E., 1926. Solnictwo. Sole kamienne, potasowe i solanki, ich własności, fizjografja, górnictwo i warzelnictwo. Cz. I (Część ogólna). Skład Główny w Księgarni Jagiellońskiej, Kraków, 181 pp. (In Polish only)

Windakiewicz, E., 1927. Solnictwo. Sole kamienne, potasowe i solanki, ich własności, fizjografja, górnictwo i warzelnictwo. Cz. III (Sól i sole potasowe w Polsce, miejsca wytwórczości). Skład Główny w Księgarni Jagiellońskiej, Kraków, 211 pp. (In Polish only) 